
\title{
CS Research Square \\ In-plane retrofitting of masonry structures by using GFRP strips in the Bedjoints
}

Fathollah Osmanzadeh

Sahand University of Technology

Elshan Ahani ( $\nabla$ elshan.ahani@gmail.com )

Shanghai Jiao Tong University https://orcid.org/0000-0002-8483-6547

\section{Behzad Rafezy}

Sahand University of Technology

\section{Mir Naghi Mousavi}

Sahand University of Technology

\section{Research Article}

Keywords: Masonry walls, Retrofitting, Seismic behavior, GFRP strips, Simplified micro modeling

Posted Date: August 17th, 2021

DOl: https://doi.org/10.21203/rs.3.rs-711691/v1

License: (c) (1) This work is licensed under a Creative Commons Attribution 4.0 International License. Read Full License 


\section{In-plane retrofitting of masonry structures by using GFRP strips in the bedjoints}

\section{Fathollah Osmanzadeh $^{1 \mathrm{a}}$, Elshan Ahani ${ }^{1 \mathrm{~b}^{*}}$, Behzad Rafezy $^{1 \mathrm{c}}$, Mir Naghi Mousavi $^{1 \mathrm{~d}}$}

${ }^{1}$ Faculty of Civil Engineering, Sahand University of Technology, Sahand New Town, Tabriz, East Azerbaijan Province, 51335/1996, Iran

\section{Abstract}

Many unreinforced masonry structures were vulnerable in the past earthquakes and required retrofitting. However, the vulnerability of masonry structures could solve by providing numerous retrofitting approaches, scarcity of appropriate methods that may provide a solution for the historical masonry structures with lesser effects on their façade is vehemently sensible. In this study, two one-third scale masonry wall specimens made by clay bricks were tested under constant vertical and cyclic lateral loading. The specimens consist of an unreinforced wall and a wall retrofitted by GFRP strips. This study investigates the seismic behavior of unreinforced masonry walls before and after using GFRP strips on their bedjoints. To this purpose, various patterns of using GFRP strips have been studied by simplified micro-modeling. The consequence indicates that the proposed retrofitting technique could improve the lateral strength and stiffness of the unreinforced masonry wall along with a considerable increase in the energy dissipation and ductility content, which leads to making a change in the behavior of the wall from brittle to ductile failure. The proposed method could apply to the modern historical structures in which cement mortar has been used as an adhesive between the masonry layers.

Keywords: Masonry walls; Retrofitting, Seismic behavior; GFRP strips; Simplified micro modeling.

\section{1- Introduction}

A large percentage of the existing buildings in the world have made of unreinforced masonry (URM) walls, many of which have not been designed by seismic codes. Manifested reports from the earthquakes in the past 50 years demonstrated that the vulnerability of URM structures to seismic excitations is much more than other types of structural systems (McGuire and Leyendecker, 1974; NAHB Research Center, 1994; D’Ayala, 2013; NZSEE Part-C8, 2017; Fabbrocino et al., 2019). Due to

${ }^{a}$ M.Sc. Graduate of Structural Engineering, Sahand University of Technology, P.O. Box 51335/1996, Sahand New Town, Tabriz, Iran, Email: fathollah.o@gmail.com

b* M.Sc. Graduate of Structural Engineering, Sahand University of Technology, P.O. Box 51335/1996, Sahand New Town, Tabriz, Iran, (corresponding author), Email: elshan.ahani@gmail.com

c Associate Professor of Structural Engineering, Department of Civil Engineering, Sahand University of Technology, P.O. Box 51335/1996, Sahand New Town, Tabriz, Iran, Email: rafezyb@sut.ac.ir

${ }^{\mathrm{d}}$ M.Sc. Graduate of Structural Engineering, Sahand University of Technology, P.O. Box 51335/1996, Sahand New

Town, Tabriz, Iran, Email: naghi_sarab@yahoo.com 
devastating earthquakes, many URM structures were thoroughly demolished (NAHB Research Center, 1994; Anagnostopoulos et al., 2004; D'Ayala and Paganoni, 2011; Dizhur et al., 2011; NZSEE Part-C8, 2017). This is while the survived URM structures are severely damaged or exposed to failure (D’Ayala and Paganoni, 2011; Dizhur et al., 2011; Bostenaru-Dan et al., 2013; Papayianni, 2015; Cannizzaro et al., 2017). Many of these structures are monumental buildings that were of value and could be an attraction point for centuries. The ingredients used as an adhesive between the layers of the masonry units in many historical buildings were lime mortar. From the initial decades of the $20^{\text {th }}$ Century, lime mortars used in masonry structures were gradually replaced by cement mortars (Gerns and Wegener, 2003), congruity of which is more than formerly used mortar layers. This issue leads to the construction of monolithic masonry structures with higher altitudes, the susceptibility of which to lateral loads is even more than the preceding. The brittle behavior of masonry units and discontinuity of load-bearing elements (Calvi et al., 2004; Lin et al., 2016) make these structures more vulnerable against lateral loads and oblige the URM walls to react as the only loadbearing system against seismic loads which barely survive. Thus almost every URM wall requires to considered for probable retrofitting methods with lesser expenses and more efficacies. In the current study, a different method of retrofitting for the modern historical masonry structures introduced. Numerous experimental (Konthesingha et al., 2013; Wang et al., 2016; Knox et al., 2018; Arslan and Celebi, 2019) and analytical (Chaimoon and Attard, 2007; Dhanasekar and Haider, 2008; Senthivel and Lourenço, 2009; Dolatshahi and Aref, 2011; Abdulla et al., 2017) researches have been performed to evaluate the seismic behavior of masonry walls. Masonry walls are the only resisting elements against earthquakes in unreinforced masonry buildings exposed to unpredicted lateral loads. Several handy techniques in past decades are proposed to improve the seismic performance of existing URM walls. The prevailing retrofitting techniques could be categorized but not limited to surface treatment like Ferro cement, shotcrete, etc. (Tasnimi and Rezazadeh, 2012; Lin et al., 2016; Shabdin et al., 2018), grout injection (Dadras et al., 2019; Doran et al., 2019; Ferreira et al., 2019), external reinforcement (FEMA 172; Borri et al., 2009; Corradi et al., 2019) and center coring (FEMA 172; Dadras et al., 2019; Paret et al., 2019). Several researchers discussed the disadvantages of these methods, like decrease in necessary space (ElGawady et al., 2004; Cannizzaro et al., 2017), increase in structural mass (ElGawady et al., 2004; Cannizzaro et al., 2017; Ferreira et al., 2019) and the loss of architectural facades (ElGawady et al., 2004; Papayianni, 2015; Dadras et al., 2019). Hence, in recent

47 decades, some researchers are concentrated on retrofitting structures by using Fiber Reinforced Polymers (FRP). The advantages of using FRP polymers are their high mechanical strength, low weight, and ease of application (Wang et al., 2017). Externally bonded FRP strips used on the masonry walls increase the tensile and shear capacity, ductility, and lateral strength during the earthquake. Many researchers have studied retrofitting of the masonry walls by using different FRP patterns (Capozucca, 2010;

51 Luccioni and Rougier, 2011; Santa-Maria and Alcaino, 2011; Kalali and Kabir, 2012a; Kalali and Kabir, 2012b). On the other 52 hand, the high cost of FRP materials which is about ten times that of structural steel disadvantage the use of FRP in the building 53 industry (Burgoyne, 2009; and Sarker et al., 2011) unless it is used in historical monuments which have priceless value and the 
utilizing amount is managed. Using FRP conveys executive difficulties and an increase in expenses. In the current study, the strips of FRP used inside the bedjoints of the wall, which to some extent decline the complicated instruction of using FRP in structural systems. FRP materials are liable to shear loads (Burgoyne, 2009) that make these substances sensitive to the sharp and

57 pointy beds. Hence in the prevailing study, the bed for these materials prepared with more accuracy, and the use of these materials in tension was controlled by numerical simulations before experimental studies. The utilization of FRP as a structural instrument facilitates many difficulties in the building industry; however, instruction deficiencies for manipulating these materials in design codes and standards are comprehensively tangible. Many premier standards consist of, but not limited to FIB 24 (2003), ACI 369R (2011), and ACI 562M (2013), have provided instruction for rehabilitation and/or retrofitting of RC

62 structures. The rehabilitation procedures of using FRP materials proffered by ACI 562M (2013) mostly referred to ACI 440.2R (2008), which do not cover the retrofitting procedures of masonry structures. FIB 24 (2003) confines the considerable extent of the retrofitting process with FRP to RC columns. En-1998-3 (2005) may consider FRP as valid retrofitting material for existing structures including masonry if it is used as a ring that wrapping the damaged or vulnerable to damaged elements. FEMA 172 (1992) proposed numerous retrofitting techniques for existing URM walls, including increasing the shear capacity by adding elements on the sides of the walls, filling the openings with appropriate elements, and using center coring. These methods do not satisfy the proposed requirements of Standards for the Treatment of Historic Properties with Guidelines for Preserving, Rehabilitating, Restoring \& Reconstructing Historic Buildings (1995) and plagiarize the 36 CFR 68 (2012) law for historic masonry structures. Utilization_of FRP as a retrofitting element for existing steel, reinforced masonry, and reinforced concrete structures are provided and consented by FIB 14 (2001), CAN/CSA-S806 (2012), CAN/CSA-S6 (2006), and FEMA 308 (1998). While many standards straightly related to unreinforced masonry structures such as FEMA P774 (2009) and ACI 530 (2011)

73 have not considered FRP as an acceptable material for retrofitting of masonry structures. However, detailed information about the 74 retrofitting procedure of historical buildings are provided by ASCE 41 (2006), only from the indirect statement sum-up of ASCE 7531 (2003) and ASCE 41 (2006), it can be deduced use of FRP to retrofitting of existing URM walls could take into consideration 76 whereas no principle for the using procedure presented. Hence, the requirement for studying the effects of FRP for both URM 77 and RM walls may be tangible.

78 Due to the different properties of mortar joints, masonry walls are considered as non-homogeneous parts. Hence, modeling of masonry structures due to anisotropy of the units, the dimension of the masonry units, joint width, material properties of the masonry units and mortar, the arrangement of bed joints and head joints, and quality of the working is considerably formidable (Lourenço, 1994). Property of the constituent materials that affect the failure mode of the masonry walls could be in diagonal, sliding along the mortar joints, toe crushing, or rocking. The test outcomes of numerous retrofitted walls with FRP polymers demonstrated that a wide variety of failure modes consist of cracking of masonry in tension, crushing of masonry in compression,

84 shear-sliding of masonry, the fiber-reinforced composite failure, delamination of FRP, or a combination of them would take 
place. In many tests, the FRP strips glued to historic clay bricks with a weak clay surface, which leads to the delamination of FRP as a dangerous mechanism of brittle failure (Capozucca, 2010). Sometimes delamination of FRP strips from masonry walls

87 before the formation of failure makes the strips inert in the retrofitting process. In this paper, the FRP strips placed inside the grooves didn't separate from the masonry wall before the failure. 2003), some of the modern historical buildings, which are not older than 100 years and constructed by cement mortar as a replacement for lime mortar could retrofit with this method. The mechanism of resistance in shear depends on the geometry of masonry panels, boundary conditions, the magnitude of the vertical loads and, characteristics of the interface bond between masonry units and mortar (Capozucca, 2011). Many of the historical monuments are consist of masonry walls that playing a crucial role in a nation as the concept of culture and tourism. Seismic vulnerability evaluation of these buildings is always one of the most significant issues in civil engineering. Hence they should retrofit by methods that won't affect the appearance and architecture besides the increase in the strength and ductility. Due to the complexity of the geometry, these buildings could not retrofit by ordinary methods. In this study, the retrofitting of masonry walls that were consist of the vertical and lateral loadbearing elements have taken into account by using a particular layout of FRP polymers. This method could use for retrofitting of the walls of historical masonry structures, which shall have diminutive effects on the façade of their well-formed edifices. The mansion of Urmia municipality, the former palace of Tabriz municipality (Sa'at Tower), Stanley Dock Tobacco Warehouse of Liverpool, Monadnock Building of Chicago, and Sheikh Safi al-Din Khānegāh and Shrine Ensemble of Ardabil are the samples with historical values which could retrofit with the proposed method. This research is an endeavor to improve the integrity of modern historical masonry structures by retrofitting them with the aid of GFRP strips which leads to the lesser interventions in their façade and residual weight of the modified structure.

\section{2- Research Significance}

Retrofitting brick walls with traditional methods has many executable problems, including considering architectural changes that are not feasible in many cases. The suitable physical and mechanical characteristics of FRP, which consist of lightweight, high strength to weight ratio, high strength in tension, moisture resistance, flexibility, durability, high stability, and corrosion resistance, have encouraged researchers to apply it. Most recent studies have dedicated to fixing FRP strips on masonry walls either vertically or horizontally (Marcari et al., 2007; Capozucca, 2010; Gattulli et al., 2017; Reboul et al., 2018). However, the applied methods that have an essential value in historical structures somehow inflict the façade. The use of FRP inside the

112 bedjoints, which is the concentration point of the current study, may somehow resolve the problem. Since the historical structures 113 are old and the bricks may not be in a row on out of plane direction or the first layer of bricks may be weathered, they do not stick well and could be the cause of detachment of the FRP strips (Prakash and Alagusundaramoorthy, 2008; Grande et al., 2013; 
115 Marcari et al., 2013). The problem referred to the inappropriate placement of the FRP strips in many cases. The modified placing 116 of the FRP strips considerably diminishes the separation and is considered a solution in this research. Retrofitting historical 117 masonries, the legacies of which should transmit to the future generation can impose substantial expenses on the nation. The high 118 outlay of the initial ingredients (Borri et al., 2009; Burgoyne, 2009; Sarker et al., 2011) and the preparation requirements 119 (Bostenaru-Dan et al., 2013; Dadras et al., 2019; Doran et al., 2019) may be the reason and proof for this allegation. Hence, an alternative method that requires lesser preparation and a more straightforward application procedure is desirable. However, due to the inexpensive value of the historical buildings satisfying the condition is hard to achieve. Therefore, using FRP inside the

122 bedjoints may decrease the complicated blueprints of retrofitting, the time, the cost, and could be applied by the workforce with

123 ease. According to numerous standards (Issue No. 376, 2007; NSET, 2009), main types of problems and basic damage patterns observed during earthquakes in masonry buildings encompass non-integrity of wall and collapse of the building due to the rapid cracking and disintegrating of the various parts and their brittle nature. In this regard, the studies could lead to proffering of better outcomes. According to many studies, low ductility (NAHB Research Center, 1994; Tasnimi and Rezazadeh, 2012; NZSEE PartC8, 2017; Dadras et al., 2019) and high weight (NZSEE Part-C8, 2017; Shabdin et al., 2018; Aghabeigi et al., 2020) accused as the main reasons of failure in masonry. This is while most of the retrofitting procedures may somehow solve the ductility but remain silent about the weight. Regarding the proffered facts, provision of a retrofitting method that increases the integrity with lesser intervention in the façade and the final weight could be of high value.

\section{3- Experimental Program}

\section{3-1- Test Setup and Instrumentation}

The specimens were constructed on a concrete foundation with $80 \mathrm{~mm}$ thickness, and the foundation connected to the rigid floor with 12 high-strength bolts. A reinforced concrete beam was mounted on the walls to apply vertical and lateral loads. The $20 \mathrm{kN}$ vertical load was applied by the $50 \mathrm{kN}$ actuator and placed on steel rolls upon the I section with direct contact to the RC beam. These rollers expand the vertical load and avoid creating false hardness due to friction. The lateral cyclic load was applied by a $1000 \mathrm{kN}$ hydraulic actuator to the concrete beam. The reaction of the walls was undertaken by the rigid floor, which does not have significant deformation under the lateral cyclic load. A $200 \mathrm{kN}$ load cell took place between the hydraulic actuator and the lateral load system. The loading procedure initiated by applying vertical load with linear increasing amplitude, and then the lateral cyclic load was applied. The lateral displacements of the walls under cyclic loading measured by LVDTs located on the upper sides of the masonry wall. Two horizontal bars on each side of the test specimen were fixed to the loading plates on the rear and former

142 faces of the wall. The loading commenced by direct loading inducement of the actuator to the former face and the reverse loading 
Fig. 2.

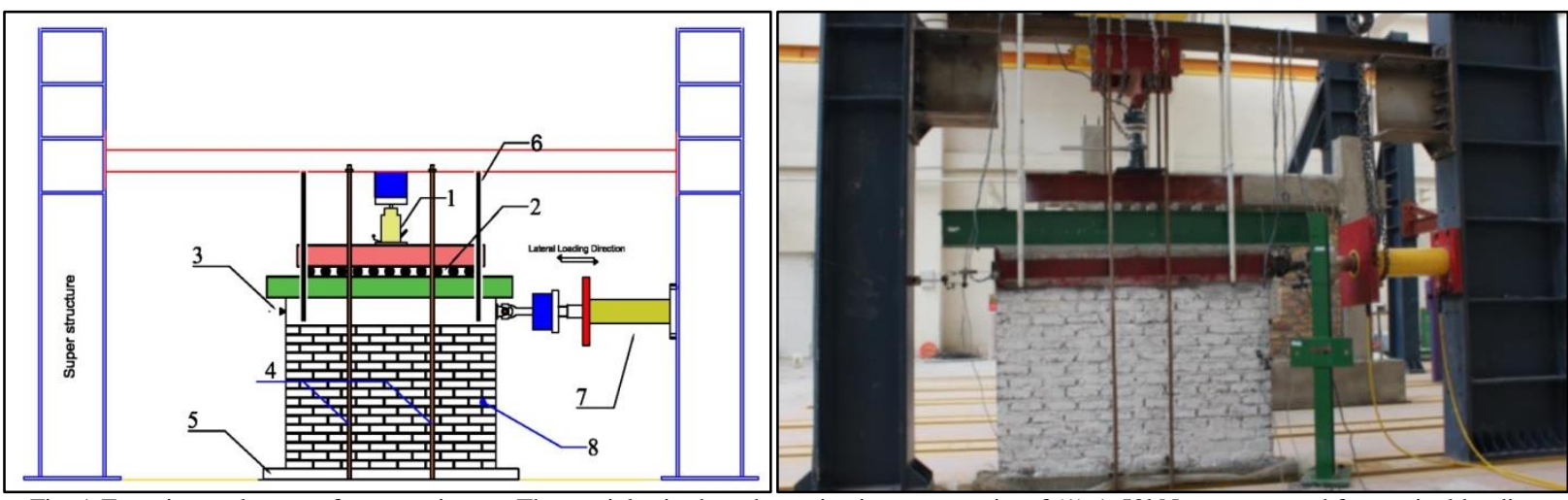

Fig. 1 Experimental setup of test specimens; The particles in the schematic view are consist of (1) A 50kN actuator used for vertical loading system, (2) Steel rolls located upon the I section, which expanding the vertical loading, (3) LVDTs located on both sides of the wall, which measures lateral displacements of the walls during the loading procedure, (4) Vertical rebars, which indirectly applying the vertical load through the vertical actuator, (5) Concrete foundation with $80 \mathrm{~mm}$ thickness, (6) Sidebars that are controlling the out of plane excitations and thwarting the overturning of the wall, (7) A 1000kN hydraulic actuator, which used for lateral loading system, (8) LVDT for measuring the out of plane displacements of the walls under cyclic loading.

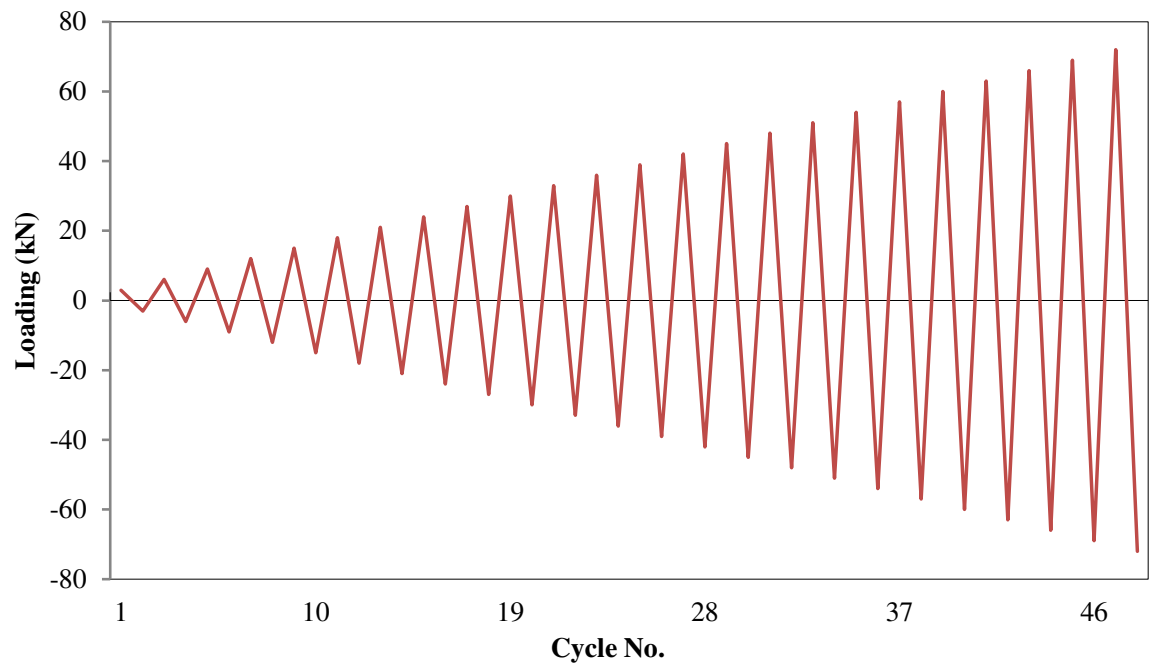

Fig. 2 Loading pattern consists of 24 force-controlled cycles in which increase in lateral load is $3 \mathrm{kN}$ for each step

\section{3-2- Test Specimens}

Because of the high expenses of fabricating experimental samples, two specimens have been mounted in the structural laboratory of the Sahand University of Technology, while the rest of the studies to ascend the depth of research performed numerically. 
Experimental studies for assuring the prosperity of the proposed method, whereas numerical studies to excavate the efficiency of that, were carried out. However, the provision of more accurate outcomes for complicated structures requires further excavation, and this study is performed to evaluate the viability of the introduced method. Concerning the principles of BHRC (2005), the width of loadbearing masonries could not be less than $200 \mathrm{~mm}$, and the length of them without tie columns could not exceed $6000 \mathrm{~mm}$. The maximum height of a masonry wall without tie beams should be less than 4000mm, accordingly. Since most of the modern historical masonries, to some extent, resided inside these limitations, a masonry wall with a respective height, width, and thickness of $3000 \mathrm{~mm}, 5250 \mathrm{~mm}$, and $300 \mathrm{~mm}$ was assumed as the prototype for this study. The selection criteria for evaluating the unreinforced masonry and the dimension also reside within the constraining principles of En-1998-1 (2004). Concerning the instrumental limitations and further execution costs, one-third scale models were constructed in the laboratory. Hence, the height, width, and thickness of the selected wall specimens with the aspect ratio of 1.74 were $1000 \mathrm{~mm}, 1740 \mathrm{~mm}$, and $100 \mathrm{~mm}$, respectively. Because of the executive restrictions, a minute difference between the aspect ratios of the prototype and

171 experimental models took place. Despite the scaling of experimental specimens, the size of masonry units was retained intact.

172 Since the provided sizes for the masonry units are various, it could be hypothetically authenticated to use smaller units to acquire 173 the required scale for the research specimens.

174 The equilibrium equation of the unreinforced masonry (URM) was allocated to determine the equivalent required GFRP strips.

175 The hypothesis of prepared equilibrium equations of the unreinforced masonry (URM) was made the design rationale and needed 176 area of GFRP strips for retrofitting. The required GFRP strip amount on each layer according to the simplifying assumptions of 177 solving the equilibrium equation has been obtained, which was extracted according to the provided explanation of Fig. 3 and 178 presented in respectively explained Eq. (1) to Eq. (3) equations.

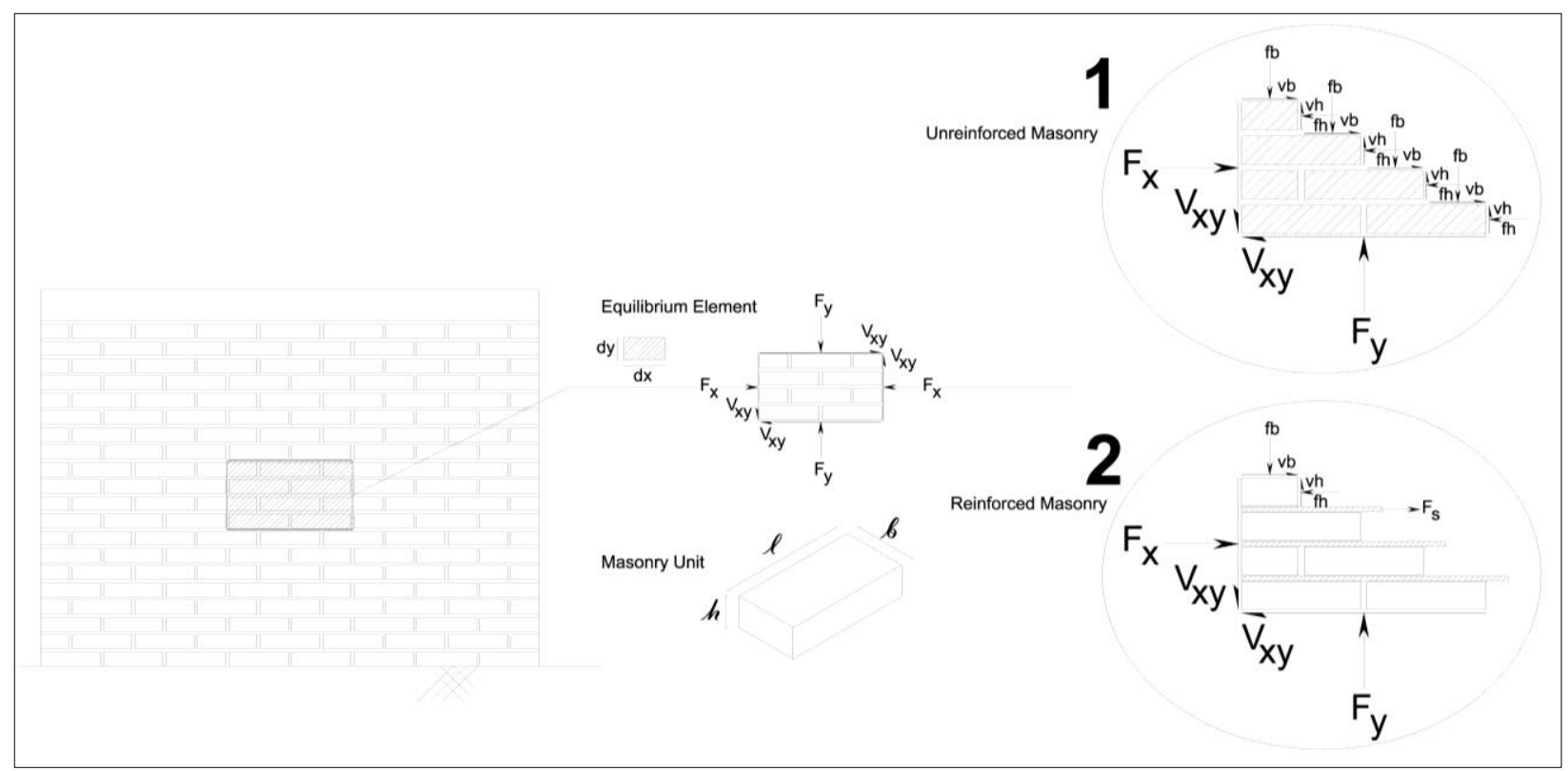




\section{Assumptions:}

(a) $\mathrm{dx} \approx \mathrm{dy}$.

(b) Properties of the headjoints and bedjoints assumed to be identical.

(c) Thickness of the joints considered to be zero.

(d) Partial variation in internal forces of equilibrium equation has neglected.

(e) Unit sizes assumed to be identical.
Equilibrium Equations:

$$
\begin{aligned}
& \sum \mathbf{F}_{\mathbf{x}}=\mathbf{0}: \mathrm{F}_{\mathrm{x}}-\sum_{\mathrm{i}=1}^{\mathrm{n}} \mathrm{fh}_{\mathrm{i}}+\sum_{\mathrm{i}=1}^{\mathrm{n}} \mathrm{vb}_{\mathrm{i}}-\mathrm{V}_{\mathrm{xy}}=0 \stackrel{\text { identical sizes }}{\longrightarrow} \mathrm{V}_{\mathrm{xy}}=\mathrm{F}_{\mathrm{x}}-\mathrm{n} \cdot \mathrm{fh}+\mathrm{n} \cdot \mathrm{vb} \\
& \sum \mathbf{F}_{\mathbf{y}}=\mathbf{0}: \mathrm{F}_{\mathrm{y}}-\sum_{\mathrm{i}=1}^{\mathrm{n}} \mathrm{fb}_{\mathrm{i}}+\sum_{\mathrm{i}=1}^{\mathrm{n}} \mathrm{vh}_{\mathrm{i}}-\mathrm{V}_{\mathrm{xy}}=0 \stackrel{\text { identical sizes }}{\longrightarrow} \mathrm{V}_{\mathrm{xy}}=\mathrm{F}_{\mathrm{y}}-\mathrm{n} \cdot \mathrm{fb}+\mathrm{n} \cdot \mathrm{vh}
\end{aligned}
$$$$
\stackrel{\text { identical properties }}{\longrightarrow}\left\{\begin{array} { l } 
{ \text { n. } f b = n \cdot f h = n f } \\
{ n \cdot v b = n \cdot v h = n v }
\end{array} \rightarrow \left\{\begin{array}{l}
V_{x y}=F_{x}-n f+n v \\
V_{x y}=F_{y}-n f+n v
\end{array} \rightarrow F_{x}=F_{y}=\mathbf{F}\right.\right.
$$

If $:\left(\mathrm{V}_{\mathrm{xy}}=\mathrm{V}\right) \rightarrow \mathbf{V}=\mathbf{F}+\mathbf{n}(\mathbf{v}-\mathbf{f})$

In which $\left\{\begin{array}{l}F \boldsymbol{\alpha} \text { Minimum strength of the masonry unit or mortar joint } \\ (v-f) \boldsymbol{\alpha} \text { Strength of the mortar joint }\end{array}\right.$

$\mathrm{F}=\min \left(\mathrm{E}_{\mathrm{m}} \varepsilon_{\mathrm{m}} \mathrm{A}, \mathrm{E}_{\mathrm{b}} \varepsilon_{\mathrm{b}} \mathrm{A}\right) \stackrel{\mathrm{A}=\mathrm{bdx}=\mathrm{bdy} \& \varepsilon_{\mathrm{m}}=\varepsilon_{\mathrm{b}}=\varepsilon}{\longrightarrow} \mathrm{F}=\operatorname{nhb} \varepsilon \cdot \min \left(\mathrm{E}_{\mathrm{m}}, \mathrm{E}_{\mathrm{b}}\right)$
$\mathrm{f}=\mathrm{E}_{\mathrm{m}} \varepsilon \mathrm{bh} \quad \& \quad \mathrm{v}=\mathrm{G}_{\mathrm{m}} \gamma \mathrm{bh}$

Fig. 3 Preparing equilibrium equation of masonry partial element for determining the retrofitting requirements of unreinforced masonry wall

$$
V= \begin{cases}n b h \gamma G_{m} & E_{b} \geq E_{m} \\ n b h\left[\varepsilon\left(E_{b}-E_{m}\right)+\gamma G_{m}\right] & E_{b}<E_{m}\end{cases}
$$

181 Where $E_{b}$ and $E_{m}$ are elasticity modulus of masonry unit and mortar joint, $b$ and $h$ are the width and thickness of the masonry

182 units, $\mathrm{n}$ is the numbers of existing layers in equilibrium element, $\gamma$ is the shear strain of the selected element, and $\mathrm{G}_{\mathrm{m}}$ is the shear modulus of mortar joint, respectively. The maximum amount of shear considering the $\mathrm{nF}_{\mathrm{s}} \geq \mathrm{V}$ inequality, where $\mathrm{F}_{\mathrm{s}}$ is the

$$
\mathrm{F}_{\mathrm{s}}=\mathrm{bh \gamma} \mathrm{G}_{\mathrm{m}}
$$

The minimum required area of GFRP strips by expanding Eq. (2) would lead to more operational relation as presented in Eq. (3).

$$
\mathrm{A}_{\mathrm{s}}=\mathrm{bh} \frac{\gamma}{2\left(1+v_{m}\right)} \frac{\mathrm{E}_{\mathrm{m}}}{\mathrm{E}_{\mathrm{s}}}
$$

Table 1 Characteristics of experimental specimens

\begin{tabular}{ccc}
\hline Description & Specimens 1 & Specimens 2 \\
& Unretrofitted Masonry Wall & Retrofitted Masonry Wall \\
\hline Height, Width and Thickness (mm) & $1000 \times 1740 \times 100$ & $1000 \times 1740 \times 100$ \\
Aspect Ratio (Width/Height) & 1.74 & 1.74 \\
Thickness of mortar joints (mm) & 10 & 10 \\
Cement/sand ratio of mortar & $1 / 3$ & $1 / 3$ \\
Masonry unit Size (mm) & $195.4 \times 98.5 \times 56.3$ & 14 \\
Number of GFRP Rows & None & 10 \\
Thickness of GFRP strips (mm) & None & \\
\hline
\end{tabular}


Masonry units made of clay are prevalent construction units in the Middle East. The average measured dimension for selected units was $195.4 \times 98.5 \times 56.3 \mathrm{~mm}$. The average thickness of mortar joints is $10 \mathrm{~mm}$ with water:cement:sand ratio of 1:2:6. The studied wall specimens are consist of a bare wall and a wall retrofitted by 10mm width GFRP strips, which placed along the bed joints on one side of the wall. In Table 1, the evaluated experimental models have demonstrated. Mechanical properties of masonry walls are affected by the characteristics of the constituent elements (bricks and mortar), the workmanship, and the interface interaction within the assemblage. The mechanical properties of bricks were determined by unidirectional compressive and tensile tests. The mean compressive strength of ten specimens of masonry units was $9.20 \mathrm{MPa}$, and the average flexural strength of the bricks was $0.31 \mathrm{MPa}$ according to ASTM C67-11 (2011) test principles. The compressive and tensile test results of the studied specimens are presented in Table 2 . The standard test results of three $\left(40 \times 40 \times 160 \mathrm{~mm}^{3}\right)$ flexural and six $\left(50 \times 50 \times 50 \mathrm{~mm}^{3}\right)$ compressive mortar samples, for 28 days curing, had an average strength of $4.10 \mathrm{MPa}$ and $33.21 \mathrm{MPa}$, respectively. The modulus of elasticity and the Poisson's ratio of concrete beams located on the wall and the rigid floor obtained according to ASTM C469/C469M-14 (2014). To determine the characteristics of masonry panels according to ASTM C1314-11 (2018), compressive and flexural strength tests were performed. The GFRP laminates were used for retrofitting the wall with the ultimate strength of $2300 \mathrm{MPa}$ and the elasticity modulus of 90GPa. The thickness of GFRP strips used for retrofitting was $0.24 \mathrm{~mm}$. The results of material tests performed to determine the properties of wall elements has shown in Table 3 .

Table 2 Test outcomes of compressive and indirect tensile strength of the masonry units

Compressive Strength Test Results

\begin{tabular}{|c|c|c|c|c|c|c|c|}
\hline Sample & $\begin{array}{c}\text { Sample } \\
\text { Dimension (mm) }\end{array}$ & $\begin{array}{c}\text { Rupture } \\
\text { Force } \\
(\mathbf{k N})\end{array}$ & $\begin{array}{l}\text { Compressive } \\
\text { Strength } \\
\text { (MPa) }\end{array}$ & Sample & $\begin{array}{c}\text { Sample } \\
\text { Dimension (mm) }\end{array}$ & $\begin{array}{c}\text { Rupture } \\
\text { Force } \\
(\mathbf{k N})\end{array}$ & $\begin{array}{c}\text { Flexural } \\
\text { Strength } \\
\text { (MPa) }\end{array}$ \\
\hline 1 & $198.5 \times 97.3$ & 185 & 9.58 & 1 & $191.5 \times 94.8 \times 55.9$ & 3.12 & 0.405 \\
\hline 2 & $186.3 \times 97.1$ & 177 & 9.78 & 2 & $194.0 \times 93.0 \times 55.9$ & 1.66 & 0.253 \\
\hline 3 & $192.3 \times 99.0$ & 180 & 9.45 & 3 & $185.0 \times 102.0 \times 55.0$ & 2.21 & 0.271 \\
\hline 4 & $195.7 \times 97.5$ & 167 & 8.75 & 4 & $194.2 \times 103.2 \times 54.0$ & 2.80 & 0.354 \\
\hline 5 & $203.5 \times 100.0$ & 250 & 12.29 & 5 & $195.7 \times 101.2 \times 58.7$ & 2.56 & 0.276 \\
\hline 6 & $202.0 \times 96.0$ & 215 & 11.09 & & & & \\
\hline 7 & $196.0 \times 96.0$ & 121 & 6.30 & & & & \\
\hline 8 & $204.2 \times 103.2$ & 151 & 7.17 & & & & \\
\hline
\end{tabular}

\section{Flexural Strength Test Results}




\begin{tabular}{cccccccc}
\hline $\mathbf{9}$ & $198.9 \times 99.0$ & 179 & 7.90 & & & & \\
$\mathbf{1 0}$ & $199.0 \times 93.0$ & 156 & 9.67 & & & & \\
& & & & & & & \\
\hline Average & $197.64 \times 97.81$ & 164.6 & 9.20 & Average & $192.08 \times 98.84 \times 55.9$ & 2.47 & 0.31 \\
\hline Deviation & $5.42 \times 2.73$ & 35.26 & 1.77 & Deviation & $4.24 \times 4.61 \times 1.75$ & 0.56 & 0.07 \\
\hline
\end{tabular}

207
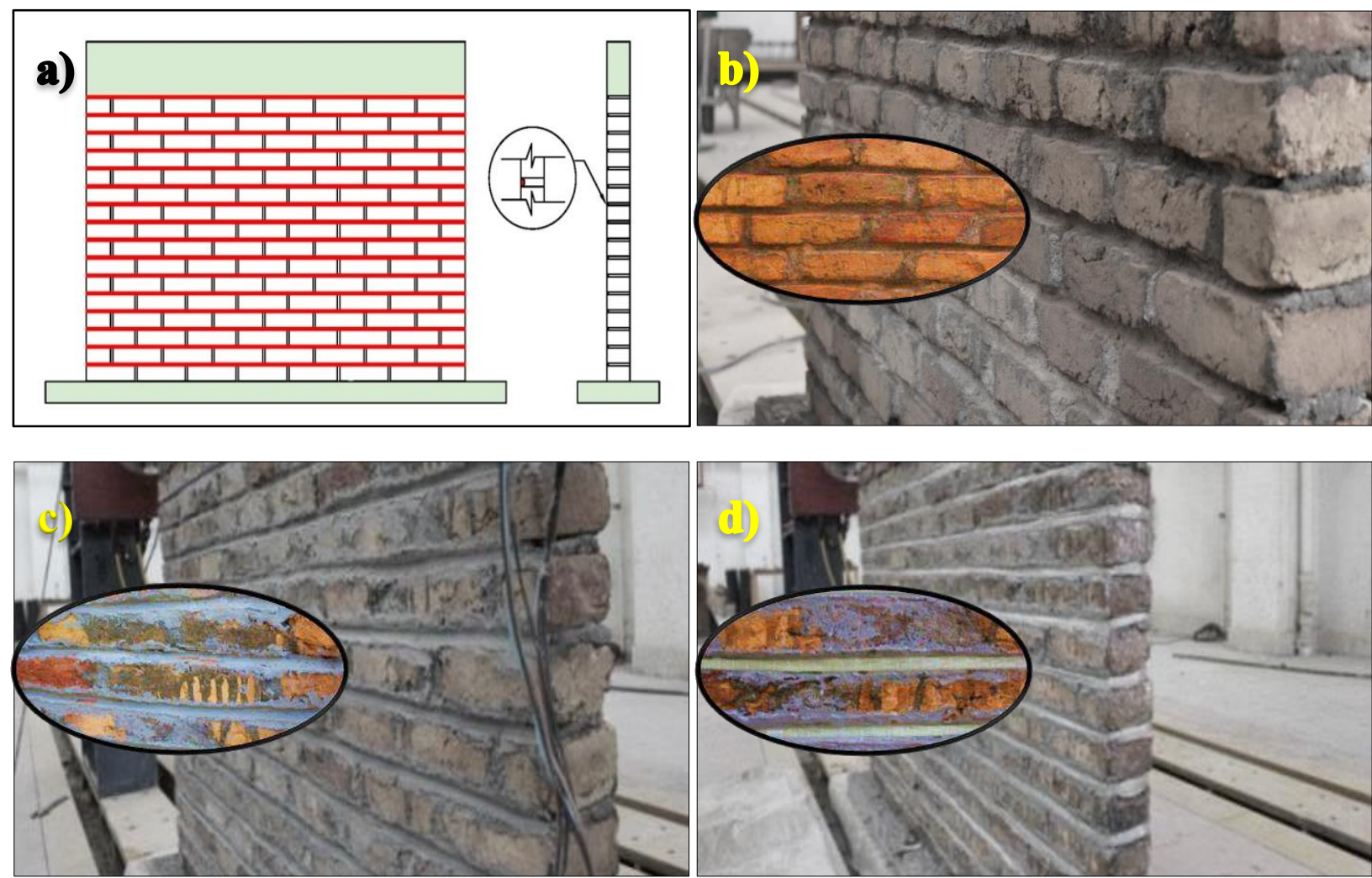

Fig. 4 Retrofitting process of Specimen 2; a) Schematic view; b) Carving of masonry layer; c) Putty pasting inside the carved layers; d) Poising

Table 3 Material Properties

\begin{tabular}{llccc}
\hline \multicolumn{1}{c}{ Material } & \multicolumn{1}{c}{ Properties } & Specimen No. & Deviation & Test Standard \\
\hline Masonry Unit & Compressive strength $=9.20 \mathrm{MPa}$ & 10 & 1.774 & ASTM C67-11 \\
& Flexural strength $=0.31 \mathrm{MPa}$ & 5 & 0.065 & ASTM C67-11 \\
\hline Concrete & Elasticity modulus $=24100 \mathrm{MPa}$ & 2 & 832.4 & ASTM C469/C469M-14 \\
& Poisson's Ratio $=0.22$ & 2 & 0.005 & ASTM C469/C469M-14 \\
\hline Mortar & Compressive strength $(28$ days $)=33.21 \mathrm{MPa}$ & 6 & 0.986 & ASTM C109/C109M-11 \\
& Flexural strength $(28$ days $)=4.10 \mathrm{MPa}$ & 3 & 0.470 & ASTM C348-08
\end{tabular}




\begin{tabular}{llccl} 
& Tensile strength $=0.06 \mathrm{MPa}$ & 5 & 0.004 & ASTM E518/E518M-15 \\
& Cohesive strength $=0.14 \mathrm{MPa}$ & 5 & 0.014 & ASCE/SEI 31-03 and ASTM G115-04 \\
& Coefficient of internal friction $=0.53$ & 5 & 0.040 & ASTM G115-04 \\
\hline GFRP Strip & Ultimate strength $=2300 \mathrm{MPa}$ & 5 & Wrap 600G & According to QUANTOM \\
& Elasticity modulus $=9 \times 10^{4} \mathrm{MPa}$ & Wrap 600G & According to QUANTOM® \\
\hline
\end{tabular}
examining the ability of the existing verified analytical models to predict the lateral strength of URM and retrofitted walls with

217 different numbers of GFRP layers.

218 The GFRP fabric cut into $20 \mathrm{~mm}$ width and $1940 \mathrm{~mm}$ length strips $(200 \mathrm{~mm}$ of the strips were bent and fixed on the unretrofitted side of the wall). Two corners of GFRP strips on one side, two times longitudinally bent over and glued to make four-layer strips afterward. Horizontal bedjoints of the retrofitted layers were carved $20 \mathrm{~mm}$ in depth to provide a poising place for the GFRP

221 strips, as it has presented in Fig. 4-b. To provide a smooth bed for FRP strips and better integrity of the wall and the strips, the 222 created cavities filled with putty, the details of which has demonstrated in Fig. 4-c. At the final stage, GFRP strips were glued into the grooves, as depicted in Fig. 4-d. The GFRP strips used on one side of the masonry, and the grooving procedure also took place on one side of the bedjoints. Since the GFRP strips used as longitudinal reinforcing elements, the requirement for the restraining of these reinforcements are tangible, and because the lapping for FRP polymers in the provided condition is practically impossible, they turned to the other side of the wall to retain the integrity of the reinforcement and barricading the possible detachments. For the longsome walls, the procedure could replace by bending the strips to the penetrated hole on the bed of the wall. According to initial numerical results placing GFRP strips in one-third of the masonry joints could satisfy the retrofitting requirements. However, to increase the reliability, all the joints filled with GFRP strips.

\section{3-3- Experimental results}

231 The experimental results of the test specimens are discussed in terms of lateral strength and drift. Fig. 5 illustrates the cracking 232 patterns of the specimens at the final stage of testing. In general, a mixed shear-flexural failure mode was observed in the test specimens. The failure of the first wall was the combination of diagonal crack and bed joint sliding, which is a brittle failure and takes place in a short fraction with sudden collapse. Specimen 1 approximately failed in $56 \mathrm{kN}$ with $0.73 \%$ drift. In the first three steps of cyclic loading for Specimen $2(10 \mathrm{kN})$, the wall was in the elastic state and, no cracking was detected. The initial flexural cracks started in the $12^{\text {th }}$ step $(37 \mathrm{kN}$ loading force and $0.38 \%$ drift). The flexural cracks expanded on both sides of the wall, and then the bricks were crushed in the lower corners due to toe-crushing failure mode. Then bed joint sliding failure occurred in the lower line of the first row. In the last stage, the wall lost its strength with the separation of FRP strips from the wall. The second specimen failed in the $24^{\text {th }}$ step ( $70 \mathrm{kN}$ loading force and $1.7 \%$ drift). The wall acts as an integrated object, and soft failure mode 
occurred according to Fig. 5-c. Detailed crack pattern and final failure of the studied specimens have provided in Fig. 5-b and 5-

241 d. Since the loading protocol is force-controlled, the load amount at every loading cycle reached the determined limits. The displacement, because of the low performance of masonries in tension, was higher in reverse loading. Hence it is assumable that

243 the hysteresis curves don't have symmetry in the displacement axis. The hysteresis curve of experimental specimens and the 244 extracted superposition of the hysteresis loops have presented in Fig. 6.

245

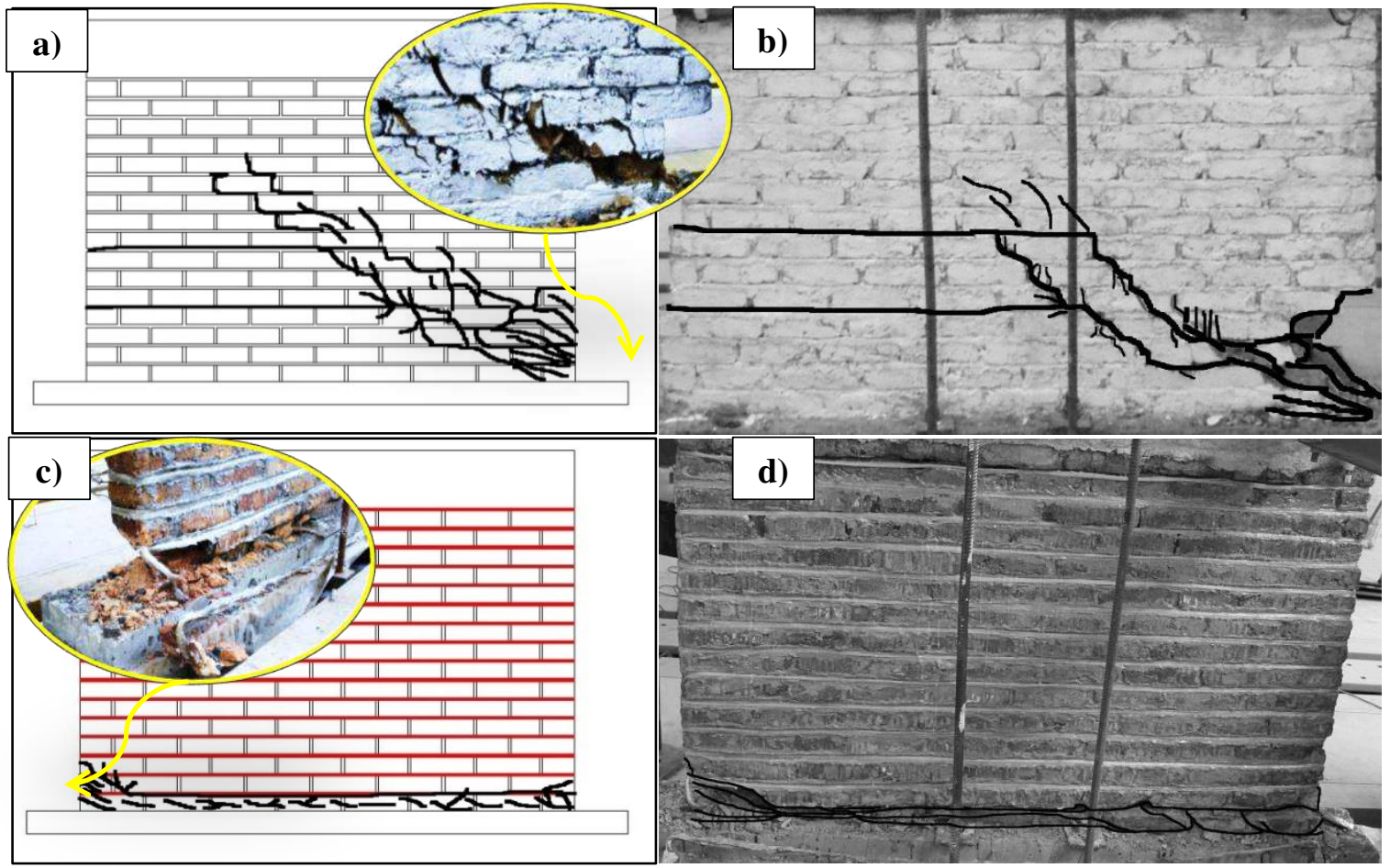

Fig. 5 The finalized crack pattern of the scrutinized specimens; a) Specimen 1; b) Schematic view of the Specimen 1; c) Specimen 2; d)

Schematic view of the Specimen 2
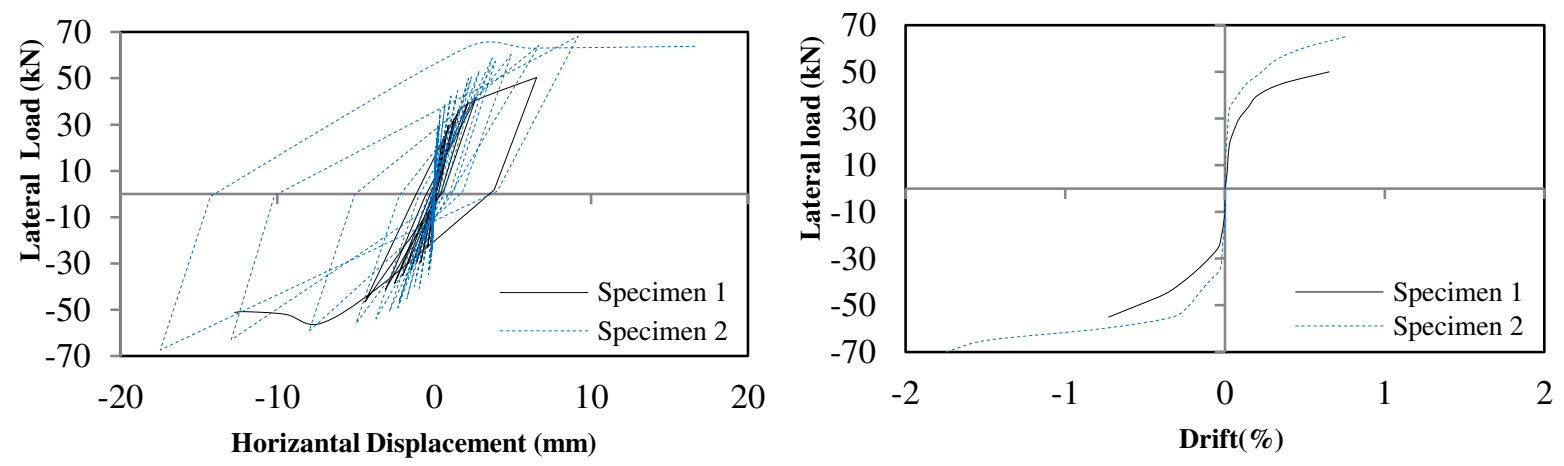

Fig. 6 Superposition of the hysteresis loops for the reference and retrofitted specimens 
The failure mode of Specimen 1 at the final stage was diagonal cracking. The period between initiation of the failure and its finalization was diminutive, which leads the structure to undertake considerable shear forces at the early stages of loading. It is inferable that the unretrofitted specimen has a brittle failure since the failure of the specimen took place in shear. However, the failure pattern in Specimen 2 initiated with flexural rocking failure and eventuated with shear toe crushing failure. The time interval of the failure for Specimen 2 is about 11 times that of Specimen 1. According to the outcomes, the retrofitting procedure changed the failure mode and provided more deformation capability to the structure. The displacement capacity of Specimen 2 is $100 \%$ more than Specimen 1. The proposed retrofitting method increases the absorbed energy approximately 2.5 times more than the unretrofitted specimen. The broader width of the load-displacement cycles displays that the energy absorption ability of the retrofitted specimen is considerably improved. The failure of the unretrofitted specimen under lower drift contents was amended by utilizing GFRP, which improved the tensile strength and prevented the sudden fracture of the masonry. Considerable increases in the flexibility of the structure due to retrofitting procedure authenticate the preliminary assumptions about the prosperity of using GFRP at the bedjoints as a retrofitting method.

Stiffness Degradation: Initial stiffness of masonry calculated by measuring the slope of the line tangent on the load-deflection curve at the origin. The elastic linear stiffness was calculated according to Tomaževič (1999). This method combines the principles of ATC-40 (1996) and FEMA440 (2005) standards, which have been established based on equal energy definition. According to this definition, the enclosed areas under the load-displacement and the ideal bilinear curve should be identical. To simplify the behavior of historical URM walls, several researchers considered idealized bilinear envelopes for horizontal force versus displacement envelops resulting from cyclic in-plane experimental behavior (Magenes and Calvi, 1997; Haach et al., 2010). Therefore, to obtain the stiffness, the secant stiffness of each cycle and peak lateral load of the $i^{\text {th }}$ cycle together with its corresponding displacement should be grasped. Since the stiffness degradation rate depends on the damage of the wall, the secant stiffness of each cycle was calculated to evaluate the evolution of damage during the loading process. The secant stiffness at each

273 loading cycle was calculated according to Eq. (4).

$$
\mathrm{k}_{\mathrm{si}}=\frac{\mathrm{H}_{\max , \mathrm{i}}}{\mathrm{d}_{\mathrm{H}_{\text {max }, \mathrm{i}}}}
$$

274 Where $\mathrm{k}_{\mathrm{si}}$ is the secant stiffness of each cycle, $\mathrm{H}_{\text {max,i }}$ is the peak lateral load of the $\mathrm{i}^{\text {th }}$ cycle, and $\mathrm{d}_{\mathrm{Hmax}, \mathrm{i}}$ is the displacement 275 corresponding to the peak lateral load of the $\mathrm{i}^{\text {th }}$ cycle. The final secant stiffness of the structure is calculated according to Eq. (5).

$$
\mathrm{k}_{\mathrm{s}}=\frac{\mathrm{H}_{\mathrm{max}}}{\mathrm{d}_{\mathrm{H}_{\max }}}
$$

276 Where $\mathrm{H}_{\max }$ is the maximum resistance of the wall during the shear test and $\mathrm{d}_{\mathrm{Hmax}}$ is the corresponding displacement. Evolution

277 of stiffness degradation for both specimens proposed according to Tomaževič (1999), which is demonstrated in Fig. 7. In the 278 same figure, the Load-displacement and bilinear curves for the studied specimens are also demonstrated. The unreinforced 

$0.6 \mathrm{~d}_{\mathrm{Hmax}}$, respectively.

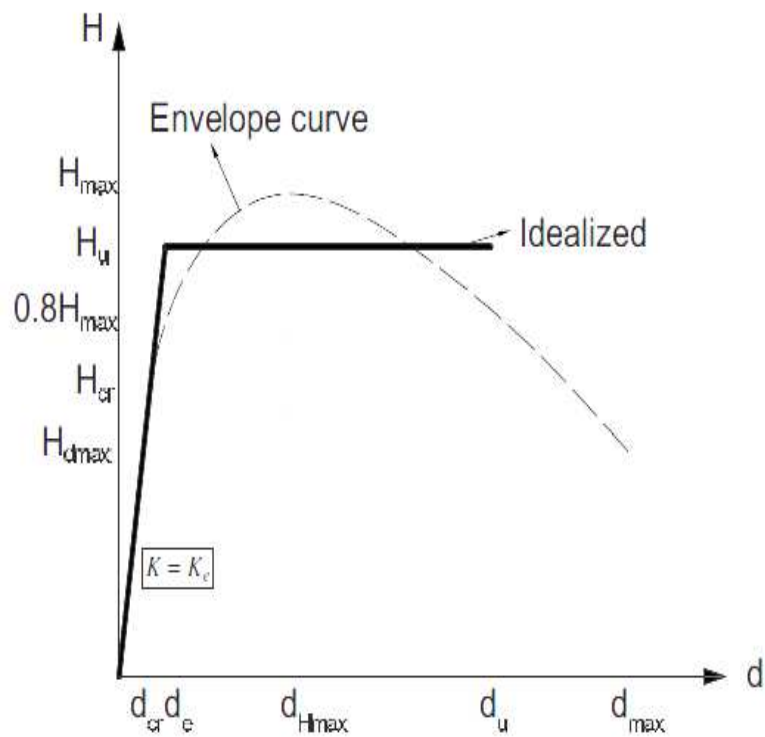

281 this definition has provided in Eq. (6).

$$
\mu_{\mathrm{u}}=\frac{\mathrm{d}_{\mathrm{u}}}{\mathrm{d}_{\mathrm{e}}}
$$

Elastic displacement can be explained by Eq. (7).

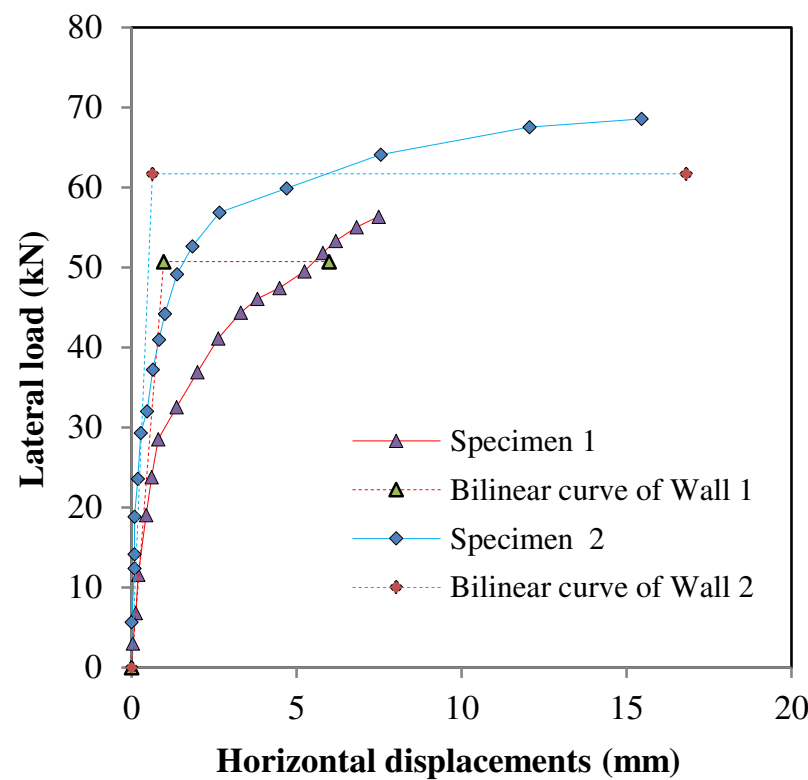

(b)

Fig. 7 (a) Bilinear idealized diagram for masonry walls proposed by Tomaževič (1999); (b) Experimental and idealized horizontal load-

$$
\text { displacement diagrams of the studied specimens }
$$

In Fig. $7, \mathrm{~d}_{\mathrm{cr}}$ is displacement corresponding to the initial cracking of the wall, $\mathrm{d}_{\mathrm{e}}$ is the elastic displacement, $\mathrm{d}_{\mathrm{Hmax}}$ is the correlating displacement with $\mathrm{H}_{\max }, \mathrm{d}_{\mathrm{u}}$ is the idealized line of displacement, $\mathrm{d}_{\max }$ ultimate horizontal displacement during the test, $\mathrm{H}_{\mathrm{dmax}}$ is ultimate horizontal force during the test, $\mathrm{H}_{\mathrm{cr}}$ is the horizontal force at the formation of the first significant cracks in the wall, $\mathrm{H}_{\mathrm{u}}$, is the ultimate load of the wall, and $\mathrm{H}_{\max }$ is Maximum horizontal force.

Ductility factor: The basic weakness of clay brick masonry structures during the earthquakes is lack of ductility, which is mistakenly considered to be lack of resistance in most cases. Ductility may determine by the bilinear curve of the loaddisplacement curve, in which the maximum displacement divide by the first yield displacement. The corresponding equation for

$$
\mathrm{d}_{\mathrm{e}}=\frac{\mathrm{H}_{\mathrm{u}}}{\mathrm{K}_{\mathrm{e}}}
$$

294 Effective stiffness of wall could be extracted from Eq. (8) which is proposed by Tomaževič (1999). 


$$
\mathrm{K}_{\mathrm{e}}=\frac{\mathrm{H}_{\mathrm{cr}}}{\mathrm{d}_{\mathrm{cr}}}
$$

The most referring value for $\mathrm{H}_{\mathbf{u}}$ is proposed by Tomaževič (1999), in which the amount of $\mathrm{H}_{\mathbf{u}}$ has considered being $90 \%$ of $\mathrm{H}_{\text {max }}$. In the current study, $\mathrm{H}_{\mathrm{u}}$ has considered being $84 \%$ of $\mathrm{H}_{\text {max }}$ according to experimental outcomes, corresponding bilinear curves, and extracted results of Tomaževič (1999). Table 4 shows the results of two-line idealization for both of the walls. According to the table, ductility and elastic stiffness haves increased in the retrofitted wall by 4.3 and 1.86 , respectively. Comparing the results by experimental outcomes illustrated a proper convergence between experimental and numerical stiffness. Comparison between the characteristics of retrofitted and unretrofitted specimens have presented in Fig. 8.

Table 4 Summary of the results for bilinear idealized curves of the studied specimens

\begin{tabular}{ccccccccc}
\hline Specimen & $\mathbf{H}_{\mathbf{c r}}$ & $\mathbf{d}_{\mathrm{cr}}$ & $\mathbf{K}_{\mathbf{e}}$ & $\mathbf{H}_{\max }$ & $\mathbf{H}_{\mathbf{u}}$ & $\mathbf{d}_{\mathbf{e}}$ & $\mathbf{d}_{\mathbf{u}}$ & $\mathbf{\mu}$ \\
& $(\mathbf{k N})$ & $(\mathbf{m m})$ & $(\mathbf{k N} / \mathbf{m m})$ & $(\mathbf{k N})$ & $(\mathbf{k N})$ & $(\mathbf{m m})$ & $(\mathbf{m m})$ & \\
\hline Specimen 1 & 29.12 & 0.56 & 52.39 & 56.38 & 50.74 & 0.97 & 5.99 & 6.2 \\
Specimen 2 & 37.1 & 0.38 & 97.63 & 68.57 & 61.71 & 0.63 & 16.81 & 26.6 \\
\hline
\end{tabular}
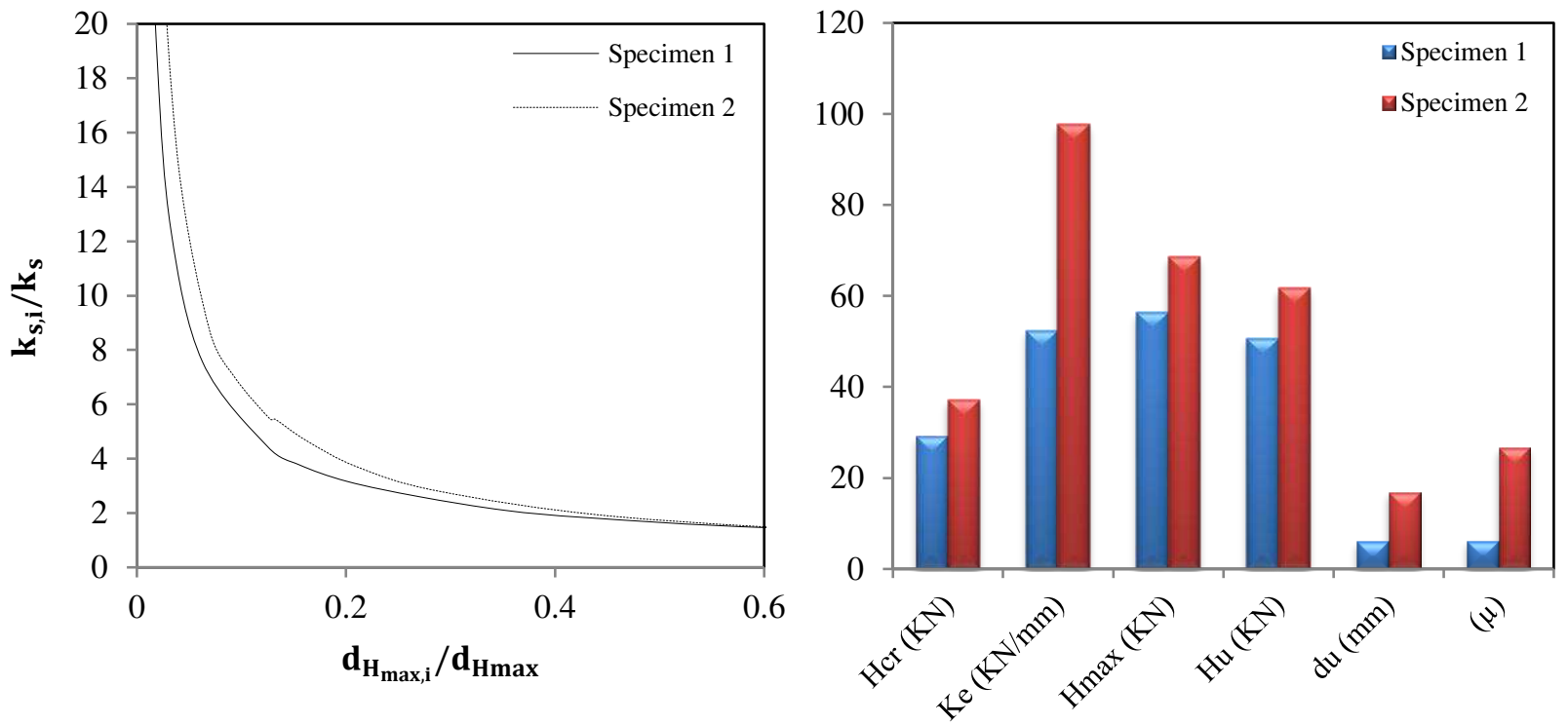
the unretrofitted and retrofitted specimens are presented in Fig. 8. By the results, the load-bearing capacity and initial stiffness of the retrofitted specimen increased by $22 \%$ and $86 \%$, respectively. The ductility content $(\mu$ ) for the retrofitted specimen is 2.29 
times more than the unretrofitted specimen. In this regard, the increase in the ductility content of the retrofitted specimen is considerably more than the corresponding increase in stiffness, which leads the behavior of the structure to ductile failure.

\section{4- Numerical Studies}

313 There are numerous valuable historical buildings with complex architecture that impose researchers to replace the priceless experimental investigations by numerical modeling and assessing their behavior during the earthquakes (Milani et al., 2017; Valente et al., 2017). According to the outcomes of many studies (Sandoval and Roca, 2012; Ahani et al., 2019), the finite element method (FEM) is the most accurate and widely used tool for analyzing masonry structures, which are also used in numerical simulations of this research. In the current study, The Concrete Damaged Plasticity criterion, a modified form of the Drucker-Prager criterion, is used for numerical simulation (Kmiecik and Kaminski, 2011).

\section{4-1- Simulation}

The simplified micro-modeling approach for numerical simulation of the masonry specimens was appropriated. According to this approach, mortar thickness and brick-mortar interfaces are squeezed to a zero-thickness surface. Afterward, the dimensions of the brick units expand to retain the geometry of a masonry wall (Senthivel and Lourenço, 2009). Joints were modeled by using interface elements and softening on both the cohesion and friction angle. Masonry units were modeled by linear 3D, eight-node cubic C3D8R elements. The CDP (Concrete Damaged Plasticity) criterion was employed to model the post-failure behavior of masonry units. The COH3D8 element was used in modeling the adhesives. Young's modulus of the wall was considered the sum of the stiffness of the bed joints and the elasticity modulus of the units, which is presented in Eq. (9) (Sandoval and Roca, 2012).

$$
\mathrm{k}_{\mathrm{n}}=0.583 \mathrm{E}_{\mathrm{b}}
$$

327 Where $k_{n}$ is the stiffness of the bed joints and $E_{b}$ is the experimentally measured Young's modulus of the masonry units.

328 Interface shear stiffness as the other elastic property of the joints by assuming the applicability of the theory of elasticity has been

329 calculated directly from the normal stiffness, which is presented in Eq. (10) (Senthivel and Lourenço, 2009).

$$
\mathrm{k}_{\mathrm{s}}=\mathrm{k}_{\mathrm{n}} /(1+\mu)
$$

330 Where $\mu$ is Poisson's ratio (which is assumed to be 0.15 ), and $\mathrm{k}_{\mathrm{s}}$ is the interface shear stiffness. The inelastic properties of the unit-mortar interface consist of tensile strength, first fracture energy, and second fracture energy, the details of which were explained in Table 5 and considered in numerical modeling (Lourenco, 1996). This adjustment has been described in more detail by Lourenco (1996), Senthivel and Lourenço (2009), and Sandoval and Roca (2012). The GFRP composite was modeled by S4R 3D shell elements, which have three rotational and three translational degrees of freedom at each node. By coupling the degrees of freedom of the solid elements to the shell elements, the mismatch between them, was reconciled. Since no separation between the GFRP strips and masonry wall during and after the test procedure was observed, it is considered that the separation between 
GFRP strips and the masonry wall won't take place. Therefore, the tie element was used for numerical modeling of the GFRPwall connection. The analyses were carried out by the direct displacement control method and considering the geometric nonlinearity. The concrete beam on top of the walls was considered rigid to reduce computational operations.

In performing the nonlinear analysis, essential factors are the loading procedure and the analysis approach (Prakash, 2008). The incremental displacement was applied to the upper beam tied to the wall and constrained in all directions except the loading axis. The incremental load amount was determined at every loading step by arc-length control scheme. At the seat, the wall was tied to the foundation, the support of which was fixed in all directions. The loading was assigned in 2 steps to simulate the experimental condition. The vertical load was applied at the first stage of the loading and occupied a quarter of the overall loading time. The lateral load was appropriated at the rest of the loading period afterward. The loading application procedure is linear. GFRP strips located between the layers of masonry units were considered to remain elastic. The thickness of the composite reinforcements considered to be $1 \mathrm{~mm}$ as it was in the experimental study. The numerical model of the masonry panel was obtained by coupling the nodes of the elements of the masonry with composite strips, which corresponds to a perfect bonding between the masonry units and the composite strips.

Table 5 Characteristics of bricks and mortar joints used in numerical modeling

\begin{tabular}{|c|c|c|c|c|c|c|c|c|}
\hline \multirow{3}{*}{ Masonry } & \multicolumn{3}{|c|}{ Elastic Properties } & \multicolumn{5}{|c|}{ Plastic Properties } \\
\hline & Young's & Poission's & \multirow{2}{*}{ Density } & \multicolumn{5}{|c|}{ Concrete Damage Plasticity } \\
\hline & Modulus & Ratio & & Dilation Angle & Eccentricity & $\mathrm{f}_{\mathrm{b} 0} / \mathrm{f}_{\mathrm{c} 0}$ & $\mathrm{~K}$ & $\mathrm{f}_{\mathrm{m}}$ \\
\hline Unit & $500 \mathrm{kgf} / \mathrm{mm}^{2}$ & 0.15 & $1.38 \times 10^{-6} \mathrm{~kg} / \mathrm{mm}^{3}$ & $27.5^{\circ}$ & 0.1 & 1.16 & 0.67 & $0.2 \mathrm{kgf} / \mathrm{mm}^{2}$ \\
\hline \multirow{3}{*}{ Mortar } & & & & \multicolumn{2}{|c|}{ Tension-Cut off } & \multicolumn{3}{|c|}{ Contact } \\
\hline & $\Lambda_{n}$ & $\mathbf{\Lambda}_{\mathrm{s}}, \mathbf{\Lambda}_{\mathrm{t}}$ & Density & $f_{n}$ & $\mathrm{f}_{\mathrm{s}}, \mathrm{f}_{\mathrm{t}}$ & No & & Hard Contact \\
\hline & $267.4 \mathrm{kgf} / \mathrm{mm}^{2}$ & $116.3 \mathrm{kgf} / \mathrm{mm}^{2}$ & $2.12 \times 10^{-6} \mathrm{~kg} / \mathrm{mm}^{3}$ & $0.016 \mathrm{kgf} / \mathrm{mm}^{2}$ & $0.022 \mathrm{kgf} / \mathrm{mm}^{2}$ & Tang & Behavior & 0.53 \\
\hline
\end{tabular}

\section{4-2- Verification}

353 In Fig. 9, the load-displacement curves obtained for the studied specimens and a comparison with experimental results have been 354 presented. The difference between the final strength of experimental and numerical models for specimens 1 and 2 are $18.2 \%$ and $35513.1 \%$, respectively. The difference between the initial stiffness of the studied specimens is $7.5 \%$ for specimen 1 and $7.7 \%$ for specimen2. The analogy of experimental and numerical specimens provides a proper convergence for the extracted results. At the

357 final stage, the cracks of specimen 1 (unretrofitted masonry) were formed with a smaller width, while due to the use of GFRP 358 strips in Specimen 2 (retrofitted masonry), a wide diagonal crack was observed. The GFRP strips were reclaiming the retrofitted wall as an integrated homogeneous object like a shear wall. This proposed method of retrofitting changed the shear-sliding 

involved in load-bearing, and this is due to the increase in the integrity of the wall. In this regard, the amount of plastic strain, which is an indicator of partial or thorough damage, is considerably decreased. The stress status of numerically evaluated specimens after applying the vertical loads and at the final stage has shown in Fig. 11.
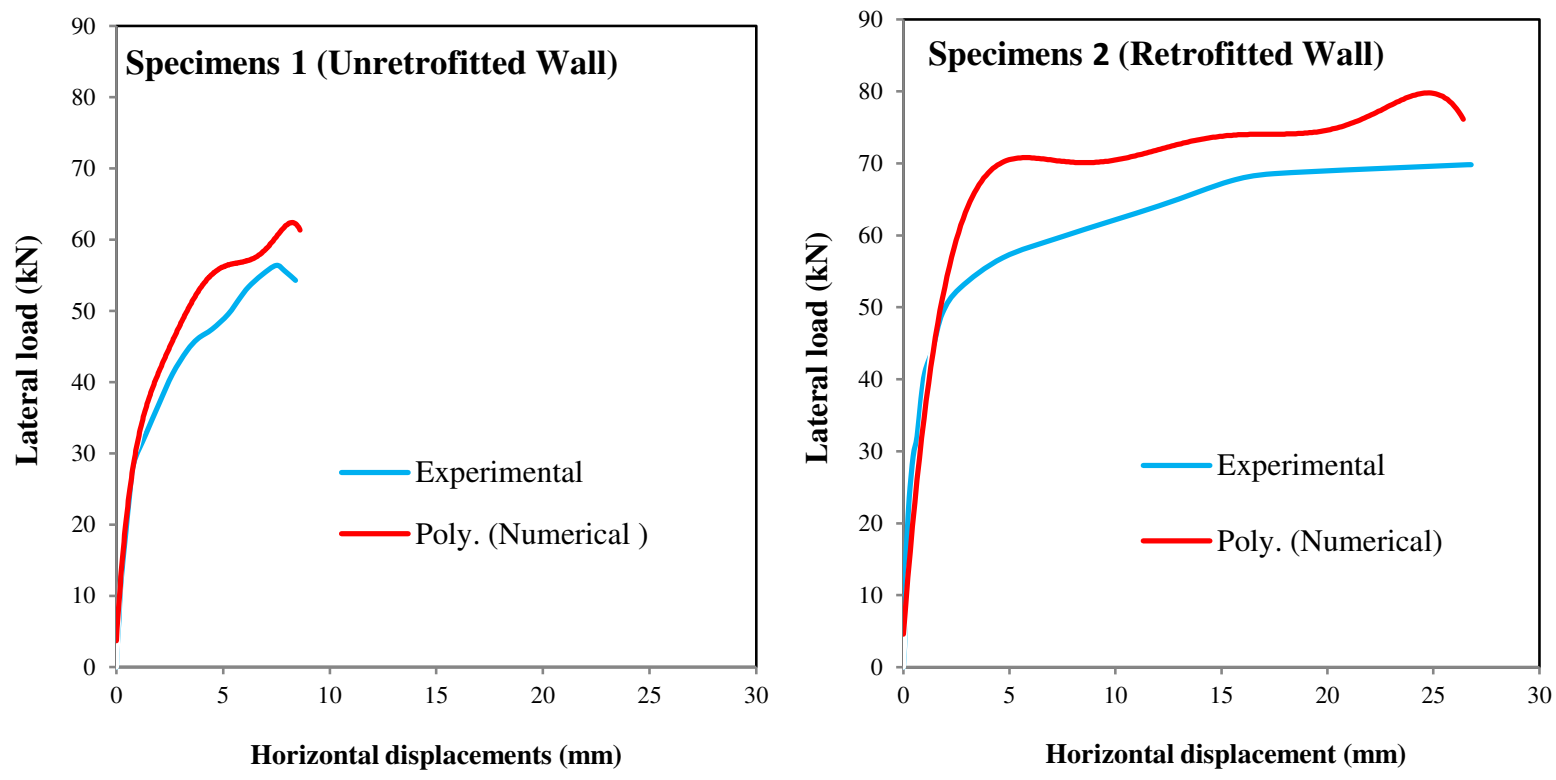

Fig. 9 Comparison of load- displacement curve of the experimentally studied specimens with numerical outcomes

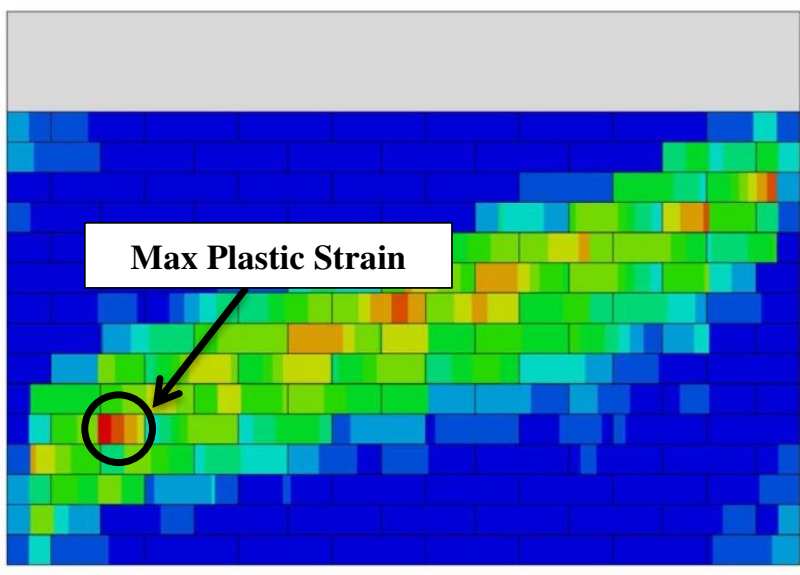




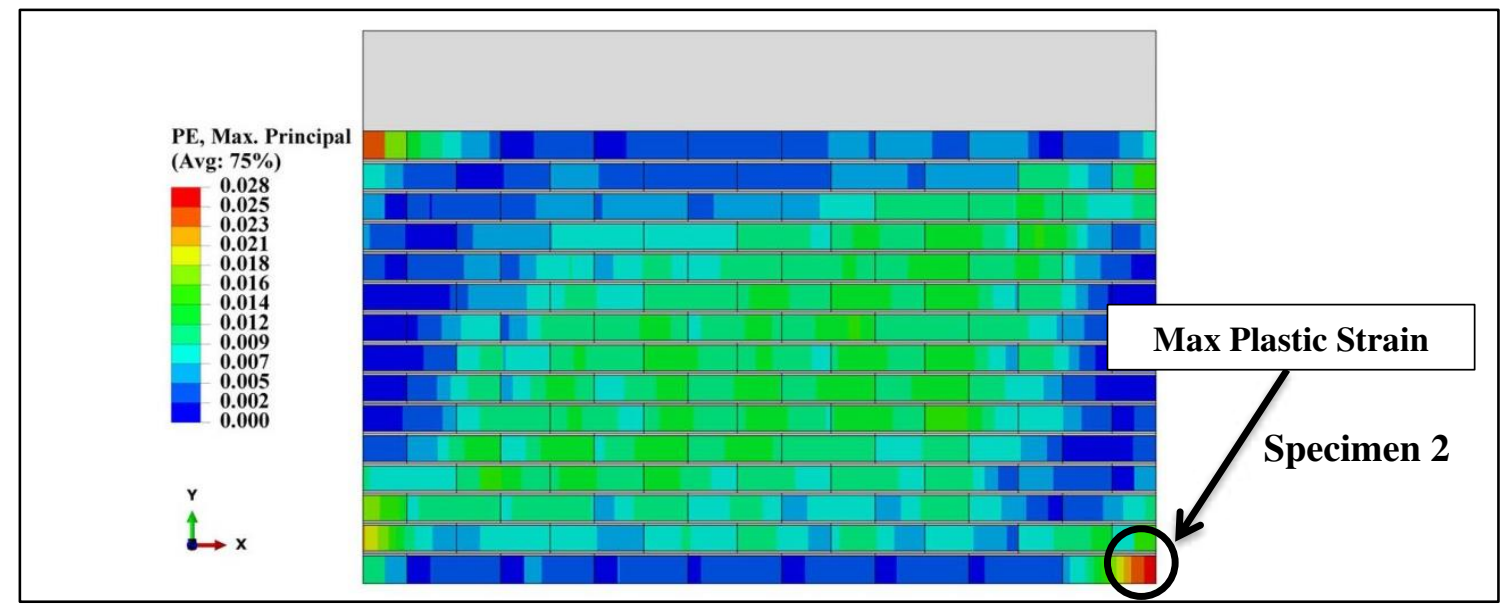

Fig. 10 Approximate crack formation places in analytical model for Specimen 1 and Specimen 2

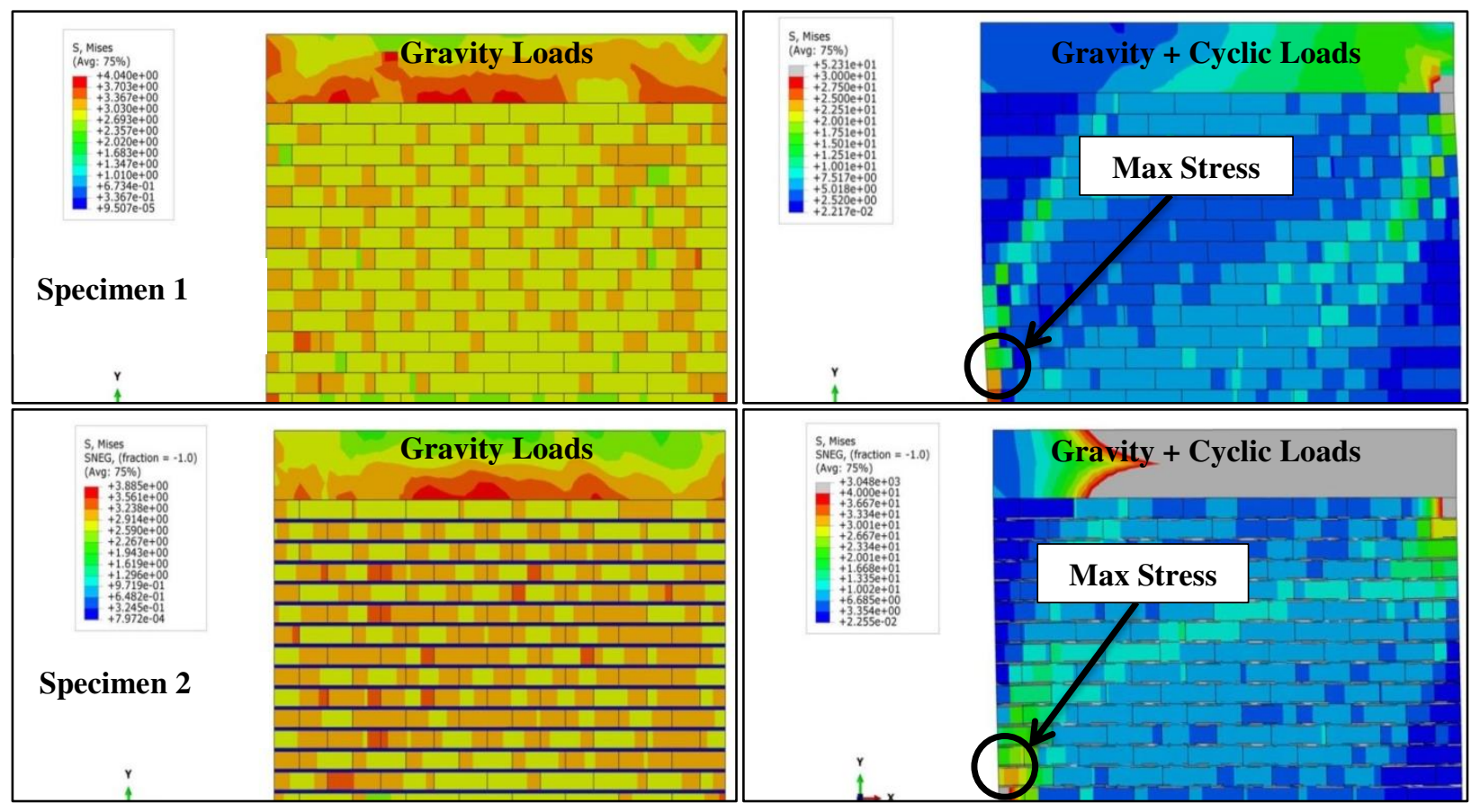

Fig. 11 Numerically evaluated specimens before and after application of cyclic horizontal loads.

372 According to the provided counters in Fig. 12, the strain value declined from $0.054 \%$ in specimen 1 to $0.028 \%$ in specimen 2 . In

373 this regard, the strain value in the retrofitted specimen halved, and in exchange, expanded to the entire wall. This homogenous expansion of the strain in specimen 2 leads to ductile rocking failure presented in the experimental study. The outcomes of the numerical analysis for specimen 1, are also covering the extracted results from the empirical research study, the observed failure of which in the unretrofitted wall occurred in brittle diagonal cracking failure.

377 According to numerical outcomes, using GFRP strips in one-third of masonry layers satisfy the expected behavior of the structure. Further numerical analyzes by reducing the number of layers is an endeavor to evaluate whether lesser GFRP strips may satisfy the anticipated behavior of the augmented masonry or the retrofitting procedure become inert. Since both the 
numerical and experimental outcomes in both of the specimens have an appropriate convergence, it is expectable that the retrofitting results of the masonries with lesser GFRP strips, the number of retrofitting layers of which reside between the initial specimens, could have acceptable accuracy.

\section{4-3- The Effects of Number of Layers}

To find the optimum reinforcement for the unretrofitted specimen by using the proposed retrofitting technique, the effect of 5 retrofitting arrangement for 3, 4, 5, 7, and 14 GFRP layers with $1 \mathrm{~mm}$ thickness on the initially evaluated wall in addition to the bare wall examined and results have compared. The increase in stiffness and strength by comparing the results with the unretrofitted specimen assessed. The arrangement of GFRP rows presented in Fig. 12. The ratio of the used GFRP strips to the wall area according to the width and the thickness of the used GFRP strip, the ultimate strength, and the strength increase ratio by comparing them to the unretrofitted specimen have presented in Table 6. By inserting 3 layers of GFRP strips in horizontal bed joints due to the small ratio of $\mathrm{A}_{\mathrm{GFRP}} /$ wall, the space between the rows of the GFRP layers does not affect the strength considerably, while the further increase of GFRP strips leads to a change in the strength increase rate from $4.5 \%$ to $12.1 \%$ (Table 6). By increasing the number of GFRP layers up to 14 layers, the strength of the wall was increased by $45.9 \%$. Placing GFRP strips in all of the horizontal bed joints from executive and economic viewpoints is problematic. Hence, considering the financial issues, the optimum layers to insert GFRP strips are ranged from 4 to 7 rows in horizontal bed joints. The stress status of further curve of numerically evaluated samples has presented in Fig. 14.

\begin{tabular}{|c|c|c|}
\hline 1 & 2 & 3 \\
\hline 4 & 5 & 6 \\
\hline$\dot{L}_{x}$ & ${ }_{2}{ }_{2}^{\nu}$ & \\
\hline
\end{tabular}


401

402

403

404

405

406

407

Fig. 12 The schematic view of the bare model and application procedure of GFRP strips in expanding numerical studies. GFRP strips considered to apply in 3 to 14 layers of initially evaluated models to consider the lateral behavior of each model and introduction of the most proper retrofitting model
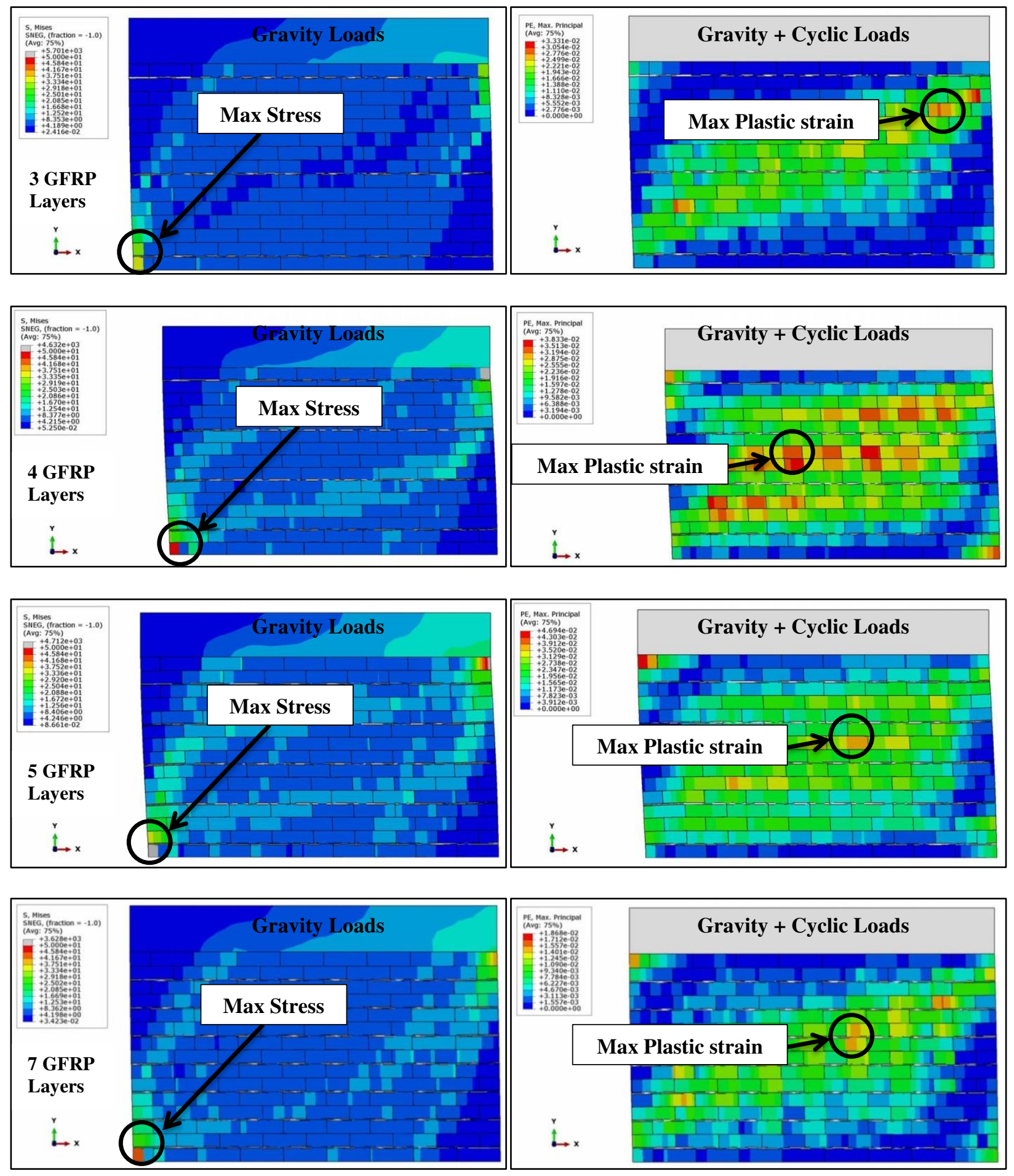

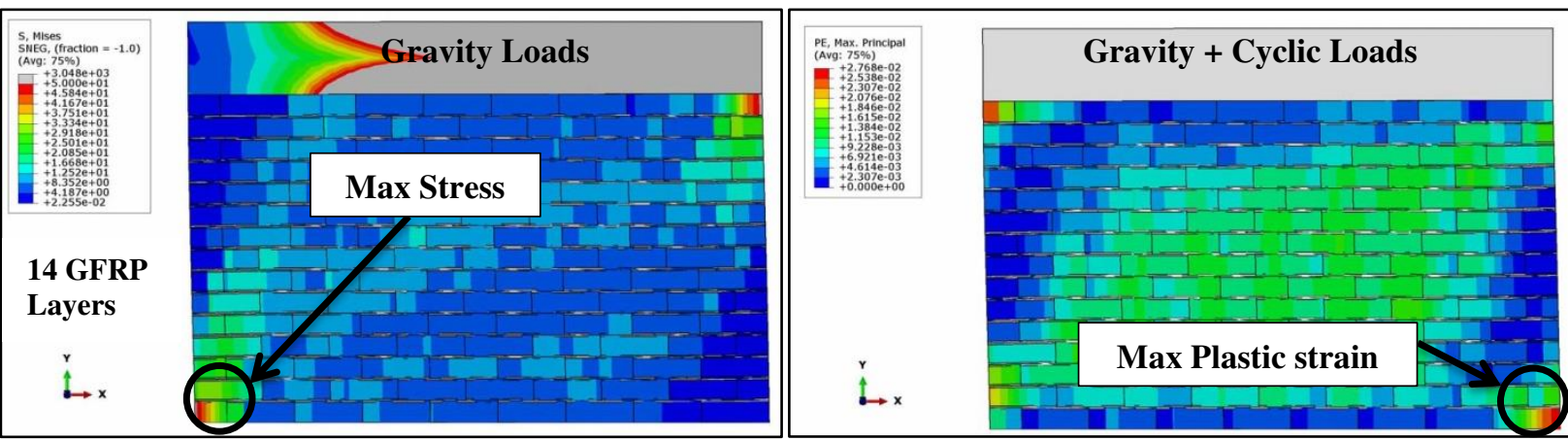

Fig. 13 The stress status of the numerically excavated specimens with different GFRP layers after application of gravity loads and at the final

stage of loading

Table 6 Used FRP percentages for retrofitting of Specimen 1 (Unretrofitted Specimen)

\begin{tabular}{|c|c|c|c|c|c|}
\hline $\begin{array}{l}\text { Model } \\
\text { Number }\end{array}$ & $\begin{array}{c}\text { Number of GFRP } \\
\text { Row }\end{array}$ & $\begin{array}{c}\text { GFRP } \\
\text { Thickness } \\
(\mathrm{mm})\end{array}$ & (AFrp/Awall) \% & $\begin{array}{c}\text { Ultimate strength } \\
\qquad(\mathrm{kN})\end{array}$ & $\begin{array}{c}\text { Increase rate } \\
(\%)\end{array}$ \\
\hline 1 & 0 & 0 & 0 & 56.11 & 0 \\
\hline 2 & 3 & 0.96 & 0.03 & 58.66 & 4.5 \\
\hline 3 & 4 & 0.96 & 0.04 & 62.85 & 12.1 \\
\hline 4 & 5 & 0.96 & 0.05 & 67.33 & 19.9 \\
\hline 5 & 7 & 0.96 & 0.07 & 70.62 & 25.8 \\
\hline 6 & 14 & 0.96 & 0.14 & 81.89 & 45.9 \\
\hline
\end{tabular}
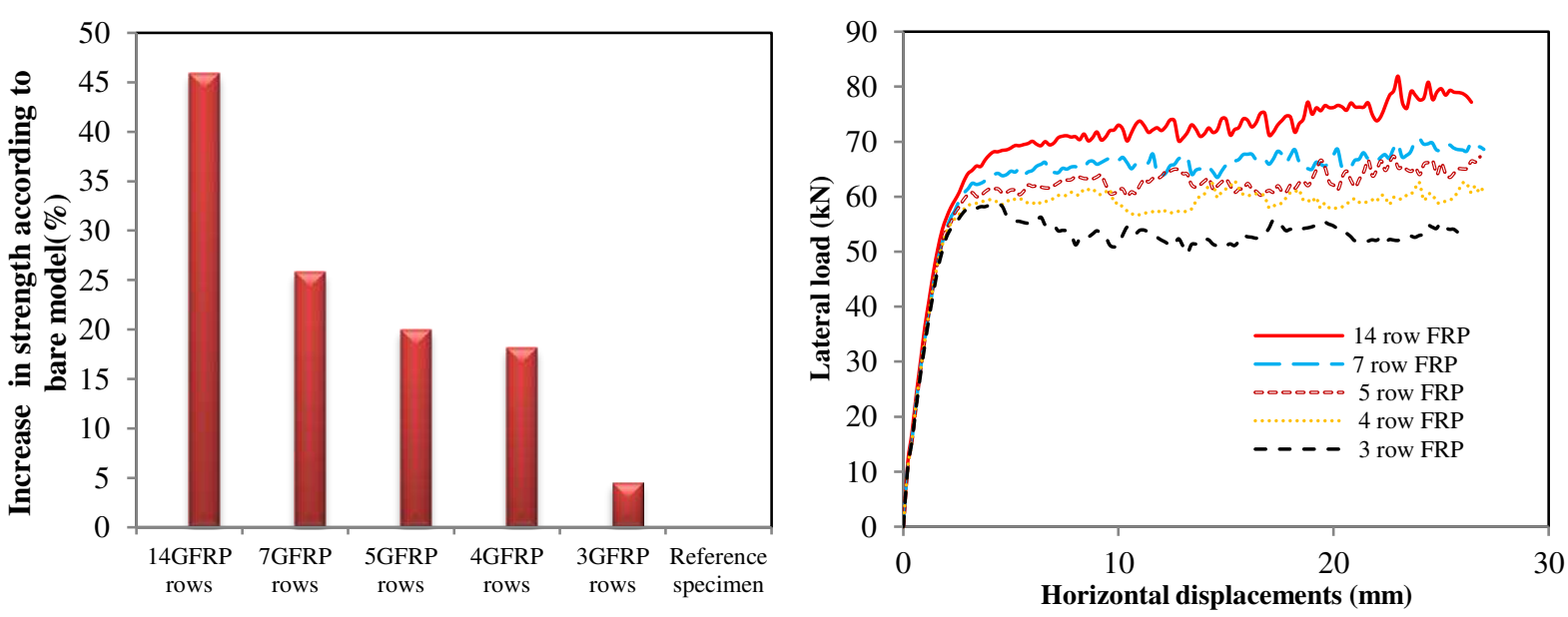


\section{5- Conclusion}

415 This study aimed to provide a method of retrofitting masonry walls, which barely affects the façade of the building in a manner that increases the ductility content of the complex. While one of the main problems of masonries is their brittle behavior, an increase in ductility could considerably improve their lateral behavior. According to the experimental and numerical experiences of this study, the following results were extracted.

- The proposed retrofitting method leads to a gradual failure of the wall. Hence, the integrity of the wall, even after failure retained. The first crack in the wall took place in the high lateral load values. Due to their high elasticity modulus and correspondingly stiffness content, FRP strips inaugurate to absorb a considerable amount of the lateral load when the cracks were created.

- Reinforcement of the wall by utilizing the proposed method increases the shear capacity, load-bearing capacity, initial stiffness, and in-plane strength. Although the intended retrofitting method increased both stiffness and ductility parameters, augmentation in ductility was more than stiffness. Since this method of retrofitting does not increase the mass of the structure, which directly leads to the absorbing of further seismic loads, the load-bearing capacity by the increase in the ductility content shall enhance.

- $\quad$ GFRP strips change the brittle failure to a soft failure mode. In the first experimentally studied specimen, the lateral load undertook with the shear strength of the mortar. Since the mortar had low shear strength, the wall collapsed in mixed diagonal crack and bed joint sliding failure mode. The second specimen has the horizontal GFRP strips, which bear the lateral forces in cooperation with the mortar shear strength. The wall loses strength from weaker row with bed joint sliding mode, failure of which was more ductile than the first studied experimental specimen.

- $\quad$ Ultimate strength, maximum displacement, and absorbed energy of the retrofitted walls with 14 rows of GFRP layers are $23.1,2.08$, and 2.5 times larger than the first experimentally studied wall, respectively. The high maximum displacement of the retrofitted wall indicates that the wall has a higher plastic content which could be a notification for collapse. The outcomes for samples with 3, 4, 5, and 7 GFRP layers are almost close, while the difference with the 14 GFRP layers is tangible.

- According to the results, a retrofitted wall converts cracks with a greater depth to small cracks with less thickness. GFRP strip makes all parts of the wall act as an integrated object and resists the lateral load. The experimental observations, which were also proved by numerical studies, demonstrate that the strain distribution in retrofitted specimens is more homogenous, leads to the formation of lesser plastic strain points in the specimens, and increases the load-bearing capacity and prosperity of the retrofitted specimens. 


\section{6- Data Availability}

444 Since some outcomes of this study didn't publish in any other Journal, all data, models, and the results that support the findings of

445 this study are available from the corresponding author upon reasonable request.

References

447

448

36 CFR 68, the Secretary of the Interior's Standards for the Treatment of Historic Properties (2012), Code of Federal Regulations, 16 U.S.C. 470 et seq.

Abdulla, K.F., Cunningham, L.S. and Gillie, M. (2017), "Simulating masonry wall behaviour using a simplified micro-model approach", Engineering Structures, 151, pp. 349-365.

Aghabeigi, P., Mahmoudi, R., Ahani, E., \& Hosseinian Ahangarnazhad, B. (2020). Seismic Assessment and Retrofitting of the Masonry Building of Mozaffarieh Timche in Tabriz Historic Bazaar. International Journal of Architectural Heritage, 1-26.

454 Ahani, E., Mousavi, M.N., Rafezy, B. and Osmanzadeh, F. (2019), "Effects of Central Opening in Masonry Infill on Lateral 455 Behavior of Intermediate RC Frames", Advances in Civil Engineering Materials, 8, 1, pp. $23-42$. American Concrete Institute, committee 369 (2011). Guide for seismic rehabilitation of existing concrete frame buildings and

457 commentary.

458 American Concrete Institute, committee 440 (2008). Guide for the Design and Construction of Externally Bonded FRP Systems for Strengthening Concrete Structures.

460 American Concrete Institute, committee 562 (2013). Code requirements for evaluation, repair, and rehabilitation of concrete 461 buildings and commentary.

462 American Society of Civil Engineers. (2007). Seismic Rehabilitation of Existing Buildings (ASCE/SEI 41-06), American Society 463 of Civil Engineers.

464 Anagnostopoulos, S., Moretti, M., Panoutsopoulou, M., Panagiotopoulou, D., \& Thoma, T. (2004). Post-earthquake damage and usability assessment of buildings: further development and applications. Final report.

466 Applied Technology Council, The Partnership for Response and Recovery, \& Federal Emergency Management Agency. (1998).

467 Repair of earthquake damaged concrete and masonry wall buildings (FEMA 308). Washington DC.

468 Arslan, M.E., Celebi, E (2019), “An experimental study on cyclic behavior of aerated concrete block masonry walls retrofitted 469 with different methods" Construction and Building Materials, 200,pp.226-239.

470 ASCE/Structural Engineering Institute. (2003). Seismic Evaluation of Existing Buildings (ASCE/SEI 31-03), American Society 471 of Civil Engineers.

472 ASTM C67-11, Standard Test Methods for Sampling and Testing Brick and Structural Clay Tile, ASTM International, West 473 Conshohocken, PA, 2011, www.astm.org. 
475 Cube Specimens), ASTM International, West Conshohocken, PA, 2011, www.astm.org.

478 ASTM E518/E518M-15, Standard Test Methods for Flexural Bond Strength of Masonry, ASTM International, West 479 Conshohocken, PA, 2015, www.astm.org. ASTM G115-04, Standard Guide for Measuring and Reporting Friction Coefficients, ASTM International, West Conshohocken, PA, 2004, www.astm.org.

482 ASTM C469/C469M-14, Standard Test Method for Static Modulus of Elasticity and Poisson's Ratio of Concrete in Compression, ASTM International, West Conshohocken, PA, 2014, www.astm.org, DOI: 10.1520/C0469_C0469M-14. Conshohocken, PA, 2018, www.astm.org, DOI: 10.1520/C1314-18. 346. Publication No. S-253, Building \& Housing Research Center, Tehran, Iran.

491 reinforced composites. Journal of composites for construction, 13(6), 468-475.

495 Burgoyne, C. (2009, July). Fibre reinforced polymers-strengths, weaknesses, opportunities and threats. In Proceedings of the 9th 496 international symposium on fiber reinforced polymer reinforcement for concrete structures (FRPRCS-9), Sydney, Australia (pp. 497 13-15).

498 Canadian Standards Association. (2006). Canadian highway bridge design code (CHBCD), CAN/CSA-S6-06. Toronto, Ontario, 499 Canada.

500 Canadian Standards Association. (2012). Design and construction of building structure with fibre-reinforced polymer, CAN/CSA 501 S806-12, Toronto, Ontario, Canada.

502 Calvi, G. M., Bolognini, D., \& Penna, A. (2004). Seismic performance of masonry-infilled RC frames: benefits of slight 503 reinforcements. Invited lecture to "Sísmica, 6, 14-16.

504 Capozucca, R. (2010), “Experimental FRP/SRP-historic masonry delamination”, Composite Structures, 92, pp. 891-903. 
Capozucca, R. (2011), "Experimental analysis of historic masonry walls reinforced by CFRP under in-plane cyclic loading",

506 Composite Structures, 94, pp. 277-289.

507 Cannizzaro, F., Pantò, B., Lepidi, M., Caddemi, S., \& Caliò, I. (2017). Multi-directional seismic assessment of historical masonry

508 buildings by means of macro-element modelling: Application to a building damaged during the L'Aquila earthquake (Italy).

509 Buildings, 7(4), 106.

510 Chaimoon, K. and Attard M.M. (2007), "Modeling of unreinforced masonry walls under shear and compression", Engineering 511 Structures, 29 , pp. 2056-2068.

512 Corradi, M., Castori, G., Sisti, R., Borri, A., \& Pesce, G. L. (2019). Repair of Block Masonry Panels with CFRP Sheets. 513 Materials, 12(15), 2363.

514 Council, B.S.S. (1992). NEHRP Handbook of techniques for the seismic rehabilitation of existing buildings (FEMA 172).

515 Washington DC.

516 D'Ayala, D.F. (2013). Assessing the seismic vulnerability of masonry buildings. In Handbook of seismic risk analysis and 517 management of civil infrastructure systems (pp. 334-365). Woodhead publishing.

518 D’Ayala, D.F., \& Paganoni, S. (2011). Assessment and analysis of damage in L'Aquila historic city centre after 6th April 2009.

519 Bulletin of Earthquake Engineering, 9(1), 81-104.

520 Dadras Eslamlou, S., Masia, M.J., Totoev, Y.Z., \& Page, A.W. (2019). Effect of retrofitting on the structural factors for seismic 521 assessment of unreinforced masonry structures: a review. Australian Journal of Structural Engineering, 20(1), 26-53.

522 Developing Successful Risk Reduction Programs, Federal Emergency Management Agency, \& Applied Technology Council 523 (2009), Unreinforced masonry buildings and earthquakes (FEMA P-774). Washington DC.

524 Dhanasekar, M. and Haider, W. (2008), "Explicit finite element analysis of lightly reinforced masonry shear walls", Computers 525 and Structures, 86, pp. 15-26.

526 Dizhur, D., Ingham, J., Moon, L., Griffith, M., Schultz, A., Senaldi, I., , Magenes, G., Dickie, J., Lissel, S., Centeno, J. and 527 Ventura, C. (2011). Performance of masonry buildings and churches in the 22 February 2011 Christchurch earthquake.

528 Dolatshahi, K.M. and Aref, A.J. (2011), "Two-dimensional computational framework of meso-scale rigid and line interface 529 elements for masonry structures", Engineering Structures, 33, , pp. 3657-3667.

530 Doran, B., Yuzer, N., Aktan, S., Oktay, D., \& Ulukaya, S. (2019). Numerical Modeling of Traditional Masonry Walls 531 Strengthened with Grout Injection. International Journal of Architectural Heritage, 1-16.

532 ElGawady, M.A., Lestuzzi, P. and Badoux, M. (2004), "A review of conventional seismic retrofitting techniques for URM", 13th 533 international brick/block masonry conference, Amsterdam, 4-7 July.

534 Eurocode, C. E. N. (2004). 8: Design of structures for earthquake resistance—Part 1: General rules, seismic actions and rules for 535 buildings, EN 1998-1. European Committee for Normalization, Brussels. 
Eurocode, C. E. N. (2005). 8: Design of structures for earthquake resistance-Part 3: Assessment and retrofitting of buildings, EN 1998-3. European Committee for Standardization: Bruxelles, Belgium.

538 Fabbrocino, F., Vaiano, G., Formisano, A., \& D'AMATO, M. (2019). Large scale seismic vulnerability and risk of masonry churches in seismic prone areas: two territorial case studies. Frontiers in built environment, 5, 102.

540 Federation Internationale du Béton (FIB). (2001). Externally Bonded Reinforcement of RC Structures: Basis of design and safety 541 concept, fib Task Group 9.3, fib Bullettin 14. International federation for structural concrete, Lausanne, Switzerland.

542 Federation Internationale du Béton (FIB). (2003). Seismic assessment and retrofit of reinforced concrete buildings. fib Task

543 Group 7.1, fib Bullettin 24. International federation for structural concrete, Lausanne, Switzerland.

544 FEMA 440, (2005), Improvement of Nonlinear Static Seismic Analysis Procedures. Applied Technology Council (ATC-55 545 Project), California.

546 Ferreira, T.M., Mendes, N., \& Silva, R. (2019). Multiscale Seismic Vulnerability Assessment and Retrofit of Existing Masonry 547 Buildings. Buildings, 9(4), 91.

548 Gattulli, V., Lofrano, E., Paolone, A. and Pirolli, G. (2017), "Performances of FRP reinforcements on masonry buildings 549 evaluated by fragility curves", Computers and Structures, 190, pp. 150-161.

550 Gerns, E.A. and Wegener, T.R. (2003), “Repointing Historic Masonry Structures” ASTM standardization news : SN; 31, 8, ISSN: 551 0090-1210, 1094-4656.

552 Grande, E., Imbimbo, M. and Sacco, E. (2013), "Finite element analysis of masonry panels strengthened with FRPs", 553 Composites: Part B, 45, pp. 1296-1309.

554 Issue No. 376, (2007), Iranian Guideline for Seismic Rehabilitation of Existing Masonry Buildings, Tehran, Iran.

555 Haach, V.G., Vasconcelos, G. and Lourenço, P.B. (2010), "Experimentally analysis of reinforced concrete block masonry walls 556 subjected to in-plane cyclic loading", J Struct Eng, 136(4), pp. 452-462.

557 Kalali, A. and Kabir, M.Z. (2012a), "Cyclic behavior of perforated masonry walls strengthened with glass fiber reinforced 558 polymers", Scientia Iranica, 19 (2), pp. 151-165.

559 Kalali, A. and Kabir, M.Z. (2012b), "Experimental response of double-wythe masonry panels strengthened with glass fiber 560 reinforced polymers subjected to diagonal compression tests”, Engineering Structures, 39, pp. 24-37.

561 Kmiecik, P. and Kaminski, M. (2011), "Modeling of reinforced concrete structures and composite structures with concrete 562 strength degradation taken into consideration”, Archives of Civil and Mechanical Engineering, 11(3), pp. 623-636.

563 Knox, C.L., Dizhur, D. and Ingham, J.M. (2018), "Experimental study on scale effects in clay brick masonry prisms and wall 564 panels investigating compression and shear related properties”, Construction and Building Materials, 163, pp.706-713. 
Konthesingha, K.M.C., Masia, M.J., Petersen, R.B., Mojsilovic, N., Simundic, G. and Page, A.W. (2013), "Static cyclic in-plane

566 shear response of damaged masonry walls retrofitted with NSM FRP strips - An experimental evaluation”, Engineering 567 Structures, 50, pp. 126-136.

568 Lin, Y., Lawley, D., Wotherspoon, L., \& Ingham, J. M. (2016, August). Out-of-plane testing of unreinforced masonry walls 569 strengthened using ECC shotcrete. In Structures (Vol. 7, pp. 33-42). Elsevier.

570 Lourenço, P.B. (1994) “Analysis of masonry structures with interface elements: Theory and applications”, Report 03-21-22-0-01,

571 Delft University of Technology, Delft, Netherlands.

572 Lourenco, P.B. (1996), Computational strategies for masonry, Delft University Press, The Netherlands, ISBN 90-407-1221-2.

573 Luccioni, B. and Rougier V.C. (2011), "In-plane retrofitting of masonry panels with fibre reinforced composite materials" 574 Construction and Building Materials, 25, pp. 1772-1788.

575 Magenes, G. and Calvi, G.M. (1997), "In-plane seismic response of brick masonry walls", Earthquake Eng Struct Dyn, 26(11), 576 pp. 1091-1112.

577 Marcari, G., Manfredi, G., Prota, A. and Pecce, M. (2007), "In-plane shear performance of masonry panels strengthened with 578 FRP”, Composites: Part B, 38, pp. 887-901.

579 Marcari, G., Oliveira, D.V., Fabbrocino G. and Lourenco, P.B. (2013), "Shear capacity assessment of tuff panels strengthened 580 with FRP diagonal layout", Composites: Part B, 42, pp. 1956-1965.

581 Masonry Standards Joint Committee. (2011). Building code requirements for masonry structures (TMS 402-11/ACI 530582 11/ASCE 5-11). The Masonry Society, Boulder, CO.

583 McGuire, W., \& Leyendecker, E. V. (1974). Analysis of Non-Reinforced Masonry Building Response to Abnormal Loading and 584 Resistance to Progressive Collapse. US Department of Commerce, National Bureau of Standards.

585 Milani, G., Shehu, R. and Valente, M. (2017), "Seismic Vulnerability Reduction of Masonry Churches: A case study", Procedia $586 \quad$ Engineering, 199, pp. 272-277.

587 National Association of Home Builders (NAHB) Research Center. (1994). Assessment of damage to residential buildings caused 588 by the Northridge earthquake.

589 National Sciety for Earthquake Technology-Nepal (NSET). (2009), Seismic Vulnerability Evaluation Guideline for private and 590 public buildings.

591 NZSEE. (2017). The Seismic Assessment of Existing Buildings: Technical Guidelines for Engineering Assessments. Part C592 Detailed Seismic Assessment. Part C8-Unreinforced Masonry Buildings.

593 Papayianni I. (2015) Retrofitting and Strengthening Masonries of Heritage Structures: Materials Used. In: Beer M., 594 Kougioumtzoglou I.A., Patelli E., Au SK. (eds) Encyclopedia of Earthquake Engineering. Springer, Berlin, Heidelberg. 
Paret, T.F., Searer, G.R. \& Freeman S.A. (2019), The Seismic Strengthening of Temple Sherith Israel, STRUCTURE magazine,

596 May.

597 Prakash, S.S. and Alagusundaramoorthy. P. (2008), "Load resistance of masonry wallettes and shear triplets retrofitted with GFRP composites", Cement \& Concrete Composites, 30, pp.745-761.

599 Reboul, N., Mesticou, Z., Si Larbi, A. and Ferrier, E. (2018), "Experimental study of the in-plane cyclic behaviour of masonry

600 walls strengthened by composite materials", Construction and Building Materials, 164, pp. 70-83.

601 Sandoval, C. and Roca, P. (2012), "Study of the influence of different parameters on the buckling behavior of masonry walls",

602 Construction and Building Materials, 35, pp. 888-899.

603 Santa-Maria, H. and Alcaino, P. (2011), "Repair of in-plane shear damaged masonry walls with external FRP”, Construction and 604 Building Materials, 25, pp. 1172-1180.

605 Sarker, P., Begum, M., \& Nasrin, S. (2011). Fiber reinforced polymers for structural retrofitting: A review. J Civil Eng, 39(1), $606 \quad 49-57$.

607 Secretary of the Interior. (1995) Standards for the Treatment of Historic Properties: With Guidelines for Preserving, 608 Rehabilitating, Restoring \& Reconstructing Historic Buildings, National Park Service, Washington D.C.

609 Senthivel, R. and Lourenço, P.B. (2009), "Finite element modelling of deformation characteristics of historical stone masonry 610 shear walls”, Engineering Structures, 31, pp. 1930-1943.

611 Shabdin, M., Attari, N.K., \& Zargaran, M. (2018). Experimental study on seismic behavior of Un-Reinforced Masonry (URM)

612 brick walls strengthened with shotcrete. Bulletin of Earthquake Engineering, 16(9), 3931-3956.

613 Tasnimi, A.A., \& Rezazadeh, M.A. (2012). Experimental and numerical study of strengthened single storey brick building under 614 torsional moment. International Journal of Civil Engineering, 10(3), 232-244.

615 Tomaževič, M. (1999), "Earthquake-resistant Design of Masonry Buildings", Imperial College Press, Volume 1 of Series on 616 innovation in structures and construction, ISBN 1860940668, 9781860940668.

617 Valente, M., Barbieri, G. and Biolzi, L. (2017), "Seismic assessment of two masonry Baroque churches damaged by the 2012

618 Emilia earthquake", Engineering Failure Analysis, 79, pp.773-802.

619 Wang, C., Forth, J.P., Nikitas, N. and Sarhosis, V. (2016), "Retrofitting of masonry walls by using a mortar joint technique; 620 experiments and numerical validation”, Engineering Structures, 117, pp. 58-70.

621 Wang, X., Ghiassi, B., Oliveira D.V. and Lam C.C. (2017), "Modeling the nonlinear behaviour of masonry walls strengthened 622 with textile reinforced mortars", Engineering Structures, 134, pp.11-24. 